\title{
Application of thermal analysis techniques to study the oxidation/ reduction phenomena during sintering of steels containing oxygen- sensitive alloying elements
}

\author{
Raquel de Oro Calderon ${ }^{1}$ (D) Christian Gierl-Mayer $^{1} \cdot$ Herbert Danninger $^{1}$
}

Received: 1 November 2015/Accepted: 27 April 2016/Published online: 18 May 2016

(C) The Author(s) 2016. This article is published with open access at Springerlink.com

\begin{abstract}
For the consolidation of steel parts manufactured by powder metallurgy (PM) techniques, removal of the surface oxides covering metallic powder particles is a necessary prerequisite. In PM steels with conventional compositions, reduction of the oxides is easily achieved in traditional sintering furnaces. However, processing steels containing alloying elements with a high oxygen affinity represents a big challenge that requires a deeper understanding of the chemical processes occurring during sintering. In the present work, thermogravimetry analysis coupled with mass spectrometry is used to describe the oxidation/reduction phenomena that take place when sintering steel powders and how these processes are modified by the addition of admixed particles containing oxygensensitive elements. Carbothermal reduction processes are studied using pure oxides $\left(\mathrm{Fe}_{2} \mathrm{O}_{3}, \mathrm{MnO}_{2}, \mathrm{Cr}_{2} \mathrm{O}_{3}\right.$ and $\left.\mathrm{SiO}_{2}\right)$ as well as water-atomized $\mathrm{Fe}$ powders mixed with small amounts - 4 mass $/ \%$ - of $\mathrm{Cr}, \mathrm{Mn}$ and $\mathrm{Si}$ powders or $\mathrm{Fe}-$ $\mathrm{Mn}-\mathrm{Si}-(\mathrm{Cr})$ master alloy powders. The results show that there is an oxygen transfer from the base iron particles to the oxidation-sensitive elements- "internal getter effect"- taking place mostly through the gas phase. Different alloying elements $(\mathrm{Cr}, \mathrm{Mn}, \mathrm{Si})$ show different temperature ranges of susceptibility to oxidation. Combination of these oxygen-sensitive alloying elements in the form of a master alloy powder reduces their sensitivity to oxidation. Also, the use of master alloys promotes the concentration of the oxides on the surface of the alloying particles and not
\end{abstract}

Raquel de Oro Calderon

raquel.oro.calderon@tuwien.ac.at

1 Institute of Chemical Technologies and Analytics, TU Wien (TUW), Getreidemarkt 9/164-CT, 1060 Vienna, Austria in the grain boundaries of the surrounding iron particlesas occurs when using Mn carriers-which should have a beneficial impact on the final mechanical performance.

Keywords Oxidation/reduction phenomena . Carbothermal reduction - Sintered steels - Oxygen-sensitive alloying elements $\cdot$ Master alloys $\cdot \mathrm{Fe}-\mathrm{Mn}-\mathrm{Si}-\mathrm{Cr}$ steels

\section{Introduction}

Sintering of steels containing oxidation-sensitive elements such as $\mathrm{Cr}, \mathrm{Mn}$ and $\mathrm{Si}$ is an important challenge for the powder metallurgy (PM) industry. Although they are standard alloying elements in the production of wrought steels, their use in PM is a difficult matter because the powder particles present a high specific surface area susceptible to oxidation. Thus, the traditional alloying elements in $\mathrm{PM}$ have been $\mathrm{Ni}, \mathrm{Cu}$ and $\mathrm{Mo}$, which form oxides with rather low thermodynamic stability, similar to those of $\mathrm{Fe}$ oxides. Even $\mathrm{H}_{2}$-containing atmospheres of fairly low purity are sufficient to remove these latter oxides during the heating stage of sintering, and the reduction is further enhanced by the admixed graphite. It is for this reason that the study of the chemical reactions has usually received much less attention by scientists than other aspects of sintering.

However, nowadays the volatile pricing of the traditional alloying elements, together with the toxicity associated with the use of $\mathrm{Ni}$ powders and the recyclability problems related to the use of $\mathrm{Cu}$, requires the introduction of new alloying alternatives. In this context, the use of alloying elements such as $\mathrm{Cr}, \mathrm{Mn}$ and Si could not only lower and stabilize the material cost, but also considerably improve the level of properties achieved. 
It has to be considered that the surface of any metallic powder is always naturally covered by an oxide. Therefore, a successful sintering process requires the elimination of the surface oxides, in order to create strong chemical contacts between particles. The reduction processes occurring during sintering take place mainly through the reaction with gaseous reducing agents from the atmosphere (in particular $\mathrm{H}_{2}$ and $\mathrm{CO}$ ) or with the admixed graphite. Hydrogen is the most effective reducing agent at low temperatures, taking care of the reduction of iron oxides layers covering most of the surface of the steel powders at temperatures around $400{ }^{\circ} \mathrm{C}$. However, the reduction of more stable oxides, or internal oxides that need high temperatures to diffuse to the powder surface, necessarily takes place at higher temperatures at which the dominant mechanism is the carbothermal reduction [1-3].

Carbothermal reduction of the oxides can take place either by reaction with graphite through the direct carbothermal reaction in Eq. 1 or through the indirect carbothermal mechanism in Eq. 2 by reaction with gaseous $\mathrm{CO}$. This latter reaction is only possible at high temperatures $\left(\sim 720{ }^{\circ} \mathrm{C}\right)$, at which the Boudouard equilibrium (Eq. 3) is shifted to the formation of $\mathrm{CO}$ and therefore favors the regeneration of $\mathrm{CO}_{2}$ into $\mathrm{CO}$ by reaction with graphite.

Traditionally, the indirect carbothermal reductionEq. 2-has been considered to be the dominant mechanism due to the higher reactivity of gaseous agents (in this case $\mathrm{CO})$ in comparison with the solid carbon. Besides, the fact that the direct carbothermal mechanism-Eq. 1-should be restricted to the contact points between metallic oxides and graphite was a further argument to consider the indirect reaction as the main mechanism. However, it should also be considered that thermodynamic stability of carbon monoxide increases with temperature (presents a positive slope in the Ellingham diagram), and therefore, from the thermodynamics point of view, the direct mechanismEq. 1-should be much more enhanced at high temperatures than the indirect one-Eq. 2. Both reduction mechanisms entail carbon losses that need to be at least controlled in order to maintain the desired final carbon content in the steel.

$$
\begin{aligned}
& (2 / y) \mathrm{Me}_{\mathrm{x}} \mathrm{O}_{\mathrm{y}}+y \mathrm{C}=(2 \mathrm{x} / \mathrm{y}) \mathrm{Me}+y \mathrm{CO} \\
& (2 / y) \mathrm{Me}_{\mathrm{x}} \mathrm{O}_{\mathrm{y}}+2 \mathrm{CO}=(2 \mathrm{x} / \mathrm{y}) \mathrm{Me}+2 \mathrm{CO}_{2} \\
& \mathrm{C}+\mathrm{CO}_{2}=2 \mathrm{CO}
\end{aligned}
$$

When oxidation-sensitive elements are used, there is a high risk of oxidation during the heating stage of sintering, when the temperature is still too low to promote reduction of the most stable oxides. The key factor for minimizing oxidation during sintering is to introduce these elements combined (i.e., alloyed) with other elements with a lower affinity for oxygen such as $\mathrm{Fe}[4,5]$. In this way, the chemical activity of the oxidation-sensitive elements can be significantly reduced. The use of prealloyed powders containing $\mathrm{Cr}$ and even $\mathrm{Mn}$ has already given a glimpse of the level of performance that can be achieved by working on the alloying system. However, the amount and type of alloying elements that can be introduced by the prealloying route are limited by their effect on powder compressibility. An alternative to prealloyed powders is the use of master alloy powders, a powder that contains all of the alloying elements and is designed to be mixed-in small amountswith an iron base powder. Thus, the final composition of the steel is achieved during sintering. This route presents advantages like the possibility to maintain the compressibility of the base powder, or the flexibility in the selection of the final composition of the steel. But one of the most interesting advantages of using master alloys is the possibility to design the composition of the master alloy to promote the formation of a liquid phase that enhances the sintering mechanisms [6]. However, it is still not well known how the specific composition of the master alloy affects the oxidation/reduction phenomena and therefore how the processing conditions have to be adapted for these new materials.

Thermogravimetry analysis coupled with mass spectrometry has proved to be the most effective method for analyzing the oxidation/reduction reactions at different stages of sintering [1-3]. Identification of critical temperature ranges with these techniques has provided the tools for an optimum design of the sintering cycles for conventional steels and even for Cr-prealloyed grades [1, 7-9].

In the present work, thermogravimetry analysis coupled with mass spectrometry is used to assess the effect of admixing small amounts of oxidation-sensitive alloying elements on the reduction/oxidation reactions occurring during sintering. A systematic study is presented starting from the analysis of the carbothermal reduction of different oxide powders to finally assess the oxidation/reduction in mixes of metallic $\mathrm{Fe}$ powders with small additions (4 mass/\%) of elemental $\mathrm{Cr}, \mathrm{Mn}$ and Si powders and Fe-Mn$\mathrm{Si}-(\mathrm{Cr})$ master alloys. The susceptibility of the reduction processes to the presence of different alloying elements is important for a future tailoring of both the master alloy compositions and the conditions required for their processing.

\section{Materials and experimental procedure}

Thermoanalytical studies were carried out using a highperformance modular simultaneous thermal analyzer Netzsch STA 449 C coupled with a quadrupole mass spectrometer (Netzsch Aeolos) by a quartz capillary. Mass 
spectrometry (MS) was used to analyze the gaseous species evolved during the thermal treatment. The masses registered in these experiments were $12(\mathrm{C}), 14(\mathrm{~N}), 15\left(\mathrm{CH}_{3}\right), 16$ $\left(\mathrm{CH}_{4}, \mathrm{O}\right), 17(\mathrm{OH}), 18\left(\mathrm{H}_{2} \mathrm{O}\right), 28\left(\mathrm{CO}, \mathrm{N}_{2}\right), 32\left(\mathrm{O}_{2}\right)$ and $44\left(\mathrm{CO}_{2}\right)$. STA was calibrated using standard routines and high temperature calibration sets (with standard metallic samples) provided by Netzsch. No specific calibration of the intensity of the ion currents was applied in QMS measurements; therefore, the results can only be interpreted qualitatively.

The characteristics of the raw materials used are presented in Table 1. Oxygen and carbon values shown in Table 1 were measured by combustion analysis using LECO TC400 and LECO CS-230, respectively, and are in good agreement with the values provided by the manufacturer. The samples used for thermal analyses consist of loose powder mixes. These mixes were homogenized in a turbula mixer for $1 \mathrm{~h}$ immediately before the analysis in order to avoid segregation. Samples of approximately $100 \mathrm{mg}$ were taken from initial powder mixes that weighed $5 \mathrm{~g}$. Table 2 presents the details of the different powder mixes used and the conditions of the experiments. The results presented in this paper correspond to experiments that were carried out at least twice in order to ensure repeatability.

The specific chemical compositions of the master alloys used in these experiments were selected to provide a liquid phase in the temperature range between 1100 and $1200{ }^{\circ} \mathrm{C}$ [10].

With the aim of ensuring that there is enough carbon to complete the reduction of the oxide powders, the stoichiometry of the mixes was adjusted to correspond to that of the reactions in Table 3 . These reactions consider a full transformation of the reactant into a carbide, which requires a higher carbon content than only the reduction of the oxide.

Powder mixes of Fe base powder with graphite and with the different alloying elements-same mixes as those used for thermal analysis-were pressed at $600 \mathrm{MPa}$ in the shape of full-size impact test bars (ISO5754). These samples were sintered for $1 \mathrm{~h}$ in $\mathrm{Ar}$ at $900{ }^{\circ} \mathrm{C}$ in a lab furnace AHT Silitstabofen. This temperature was chosen after analyzing the results from thermal analyses, and it is a critical temperature at which all the alloying powders studied presented a tendency to oxidation. After sintering, the samples were cooled at approximately $0.75{ }^{\circ} \mathrm{C} \mathrm{s}^{-1}$, in a water-jacketed exit zone under the same protective atmosphere. These pressed and sintered samples were then prepared for metallographic examination. Both the cross section and the fracture surface of the sintered samples were examined with a scanning electron microscope. Qualitative identification of the chemical composition of the sample in specific points or areas of the examined surfaces was obtained with an integrated energy dispersive X-ray spectroscopy (EDS) detector. For the sake of simplicity, the results from EDS analyses have been represented as numerical values; however, this information can only be qualitatively interpreted, as quantitative evaluation is not possible.

\section{Results and discussion}

\section{Carbothermal reduction of oxides}

In order to set the basis for analyzing the carbothermal reduction of the oxides covering metallic powder particles, carbothermal reduction of different powdered oxides was studied using differential thermal analysis/thermogravimetry (DTA/TG) coupled with mass spectrometry (MS).

Table 4 presents the mass losses expected for the reduction of different oxides, considering two extreme scenarios: the exclusive formation of either $\mathrm{CO}$ or $\mathrm{CO}_{2}$ as a product of the global reaction. The reactions presented in Table 4 assume the full transformation into carbides which is rather unlikely to occur. However, the theoretical mass loss — which is the data of interest—would not be affected

Table 1 Summary of the materials used in the different studies

\begin{tabular}{ll}
\hline Oxide powders & Sigma Aldrich: $\mathrm{SiO}_{2}$ white quartz sand, $\mathrm{MnO}_{2}$ chunks and powder, $\mathrm{Cr}_{2} \mathrm{O}_{3}$ powder, $\mathrm{Fe}_{2} \mathrm{O}_{3}$ powder $d_{90}=5 \mu \mathrm{m}$, \\
& $\mathrm{Fe}_{2} \mathrm{MnO}_{4}$ nano-powder $d_{90}=50 \mathrm{~nm} . \mathrm{Purity} \geq 99.995 \%$. Sieved $<45 \mu \mathrm{m}$ \\
Base Fe powder & Water-atomized iron powder grade ASC 100.29, Höganäs AB Sweden $\mathrm{O}<0.08$ mass $/ \%, \mathrm{C}<0.01$ mass $/ \%$, \\
& $d_{50} \sim 80 \mu \mathrm{m}$ \\
Graphite powder & Natural graphite grade UF4, Kropfmühl \\
Elemental alloying & Sigma Aldrich: $\mathrm{Si}, \mathrm{O}<0.5$ mass $/ \% ; \mathrm{Mn}, \mathrm{O}<2$ mass $/ \%$; Cr O $<1$ mass $/ \%$. Purity $\geq 99 \%$. Sieved $<45 \mu \mathrm{m}$ \\
powders & \\
Master alloy powders & Gas atomized in $\mathrm{N}_{2}$ in a pilot scale atomizer at University Carlos III of Madrid \\
& Compositions in mass $/ \%:$ MA1: Fe-40Mn-17Si, MA2: Fe-40Mn-15Si-1C and MA3: Fe-40Mn-10Si-15Cr-0.5C \\
& Sieved $<45 \mu \mathrm{m}, d_{50} \sim 20 \mu \mathrm{m}, \mathrm{O}<0.05$ mass $/ \%$ \\
\hline
\end{tabular}


Table 2 Summary of experimental details

\begin{tabular}{|c|c|c|}
\hline Sample & Experiment & Atmosphere \\
\hline Mixes of oxide powders with graphite & DTA/TG + MS & Ar 5.0, purity $99.999 \%$, \\
\hline Stoichiometry adjusted to fit the reactions in Table 3 & $1500{ }^{\circ} \mathrm{C}$ & flow $100 \mathrm{~mL} \mathrm{m^{-1 }}$ \\
\hline $\begin{array}{l}\text { Mixes of base } \mathrm{Fe} \text { powder with } 0.5 \text { mass } / \% \mathrm{C} \text { and } \\
4 \text { mass } / \% \text { of alloying elements: }\end{array}$ & Heating/cooling $\sim 20{ }^{\circ} \mathrm{C} \mathrm{min}-1$ & \\
\hline
\end{tabular}

4 mass $/ \%$ of alloying elements:

(a) $\mathrm{Si}, \mathrm{Mn}$ or $\mathrm{Cr}$ or (b) MA1, MA2 or MA3

Table 3 Reactions used to determine the stoichiometry of the mixes with oxides

$$
\begin{aligned}
& \mathrm{Fe}_{2} \mathrm{O}_{3}+11 / 3 \mathrm{C}=2 / 3 \mathrm{Fe}_{3} \mathrm{C}+3 \mathrm{CO} \\
& \mathrm{Fe}_{2} \mathrm{MnO}_{4}+17 / 3 \mathrm{C}=2 / 3 \mathrm{Fe}_{3} \mathrm{C}+\mathrm{MnC}+4 \mathrm{CO} \\
& \mathrm{Cr}_{2} \mathrm{O}_{3}+13 / 3 \mathrm{C}=2 / 3 \mathrm{Cr}_{3} \mathrm{C}_{2}+3 \mathrm{CO} \\
& \mathrm{MnO}_{2}+3 \mathrm{C}=\mathrm{MnC}+2 \mathrm{CO} \\
& \mathrm{SiO}_{2}+3 \mathrm{C}=\mathrm{SiC}+2 \mathrm{CO} \\
& \mathrm{MnO}_{2}+2 \mathrm{Fe}+11 / 3 \mathrm{C}=2 / 3 \mathrm{Fe}_{3} \mathrm{C}+\mathrm{MnC}+2 \mathrm{CO}
\end{aligned}
$$

if instead of the formation of carbides, formation of metallic species plus an excess of carbon was considered.

Exclusive formation of $\mathrm{CO}$ during reduction might suggest that the direct carbothermal mechanism is the dominant reaction, but it is also theoretically possible if the indirect carbothermal mechanism is dominant. Taking as example the reduction of $\mathrm{FeO}$ : If the indirect carbothermal mechanism prevails (Eq. 10), supposing that all of the $\mathrm{CO}_{2}$ is regenerated to form $\mathrm{CO}$ through the reaction with carbon (Eq. 3), the overall reduction reaction (Eq. 11) would be exactly that of the direct carbothermal reaction. This implies that the gaseous product detected in the mass spectrometer would be exclusively $\mathrm{CO}$, and the mass losses observed would be exactly the same in both cases. This of course requires the assumption that all of the $\mathrm{CO}_{2}$ is immediately regenerated to $\mathrm{CO}$ before it can leave the sample. Such complete regeneration should be more probable in compacts than in loose powder mixes, as in the first case evacuation of $\mathrm{CO}_{2}$ from the sample is slower.

$\mathrm{FeO}+\mathrm{CO}=\mathrm{Fe}+\mathrm{CO}_{2}$

$\mathrm{FeO}+\mathrm{C}=\mathrm{Fe}+\mathrm{CO}$

The reactions with exclusive formation of $\mathrm{CO}_{2}$ presented in Table 4 are possible only at low temperatures (below the Boudouard equilibrium), at which $\mathrm{CO}_{2}$ is more stable than $\mathrm{CO}$. Therefore, exclusive formation of $\mathrm{CO}_{2}$ can only take place in case of having a dominant indirect reduction that fully consumes the $\mathrm{CO}$, and if also the $\mathrm{CO}_{2}$ formed is only partially regenerated to $\mathrm{CO}$. An example of this is showed by the reactions in Eqs. 12 and 13, with Eq. 14 being the global reaction. As can be seen in Table 4, with exclusive formation of $\mathrm{CO}_{2}$, the mass losses would be considerably lower than in case of exclusive formation of $\mathrm{CO}$.
Table 4 Theoretical mass losses expected for the reduction of the oxides by two different mechanisms considering the specific stoichiometry of the mixes used in this study

\begin{tabular}{ll}
\hline $\mathrm{Reaction}$ & $\begin{array}{l}\text { Theoretical } \\
\text { mass } \\
\text { loss } / \%\end{array}$ \\
\hline $\mathrm{Fe}_{2} \mathrm{O}_{3}+11 / 3 \mathrm{C}=2 / 3 \mathrm{Fe}_{3} \mathrm{C}+3 \mathrm{CO}$ & 41.25 \\
$\mathrm{Fe}_{2} \mathrm{O}_{3}+11 / 3 \mathrm{C}=2 / 3 \mathrm{Fe}_{3} \mathrm{C}+3 \mathrm{C}+3 / 2 \mathrm{CO}_{2}$ & 32.40 \\
$\mathrm{Fe}_{2} \mathrm{MnO}_{4}+17 / 3 \mathrm{C}=2 / 3 \mathrm{Fe}_{3} \mathrm{C}+\mathrm{MnC}+4 \mathrm{CO}$ & 37.51 \\
$\mathrm{Fe}_{2} \mathrm{MnO}_{4}+17 / 3 \mathrm{C}=2 / 3 \mathrm{Fe}_{3} \mathrm{C}+\mathrm{MnC}+2 \mathrm{C}+2 \mathrm{CO}_{2}$ & 18.75 \\
$\mathrm{Cr}_{2} \mathrm{O}_{3}+13 / 3 \mathrm{C}=2 / 3 \mathrm{Cr}_{3} \mathrm{C}_{2}+3 \mathrm{CO}$ & 41.18 \\
$\mathrm{Cr}_{2} \mathrm{O}_{3}+13 / 3 \mathrm{C}=2 / 3 \mathrm{Cr}_{3} \mathrm{C}_{2}+3 / 2 \mathrm{C}$ & 32.35 \\
$+3 / 2 \mathrm{CO}$ & \\
$\mathrm{MnO}_{2}+3 \mathrm{C}=\mathrm{MnC}+2 \mathrm{CO}$ & 45.55 \\
$\mathrm{MnO}_{2}+3 \mathrm{C}=\mathrm{MnC}+\mathrm{C}+\mathrm{CO}_{2}$ & 35.79 \\
$\mathrm{SiO}_{2}+3 \mathrm{C}=\mathrm{SiC}+2 \mathrm{CO}$ & 58.28 \\
$\mathrm{SiO}_{2}+3 \mathrm{C}=\mathrm{SiC}+\mathrm{C}+\mathrm{CO}_{2}$ & 45.78 \\
$\mathrm{MnO}_{2}+2 \mathrm{Fe}+11 / 3 \mathrm{C}=2 / 3 \mathrm{Fe}_{3} \mathrm{C}$ & 23.09 \\
$+\mathrm{MnC}_{2} \mathrm{CO}$ & \\
$\mathrm{MnO}_{2}+2 \mathrm{Fe}+11 / 3 \mathrm{C}$ & 18.14 \\
$=2 / 3 \mathrm{Fe}$ & $\mathrm{C}+\mathrm{MnC}+\mathrm{C}+\mathrm{CO}_{2}$ \\
\hline
\end{tabular}

$\mathrm{FeO}+\mathrm{CO}=\mathrm{Fe}+\mathrm{CO}_{2}$

$1 / 2 \mathrm{C}+1 / 2 \mathrm{CO}_{2}=\mathrm{CO}$

$\mathrm{FeO}+1 / 2 \mathrm{C}=\mathrm{Fe}+1 / 2 \mathrm{CO}_{2}$

DTA/TG signals obtained during the reduction of $\mathrm{Fe}_{2} \mathrm{O}_{3}$ as well as the relevant masses detected in the mass spectrometer $-m / z 28(\mathrm{CO})$ and $m / z, 44\left(\mathrm{CO}_{2}\right)$ - are represented in Fig. 1a. The mass losses registered in the thermogravimetry curve take place simultaneously with the evolution of $\mathrm{CO} / \mathrm{CO}_{2}$ gaseous species. In addition, the reduction processes are also registered as endothermic peaks in the DTA signal.

Figure $1 \mathrm{~b}$ shows a detail of the curves from Fig. 1a in the temperature range between 500 and $1100{ }^{\circ} \mathrm{C}$. In this experiment, the mass loss starts at $\sim 820^{\circ} \mathrm{C}$ and initially $\mathrm{m} / \mathrm{z} 44\left(\mathrm{CO}_{2}\right)$ is preferentially formed. There is a first reduction stage represented by a peak in $m / z 44\left(\mathrm{CO}_{2}\right)$ at $900{ }^{\circ} \mathrm{C}$ with a simultaneous mass loss. The mass loss registered for this first process-measured right before the 

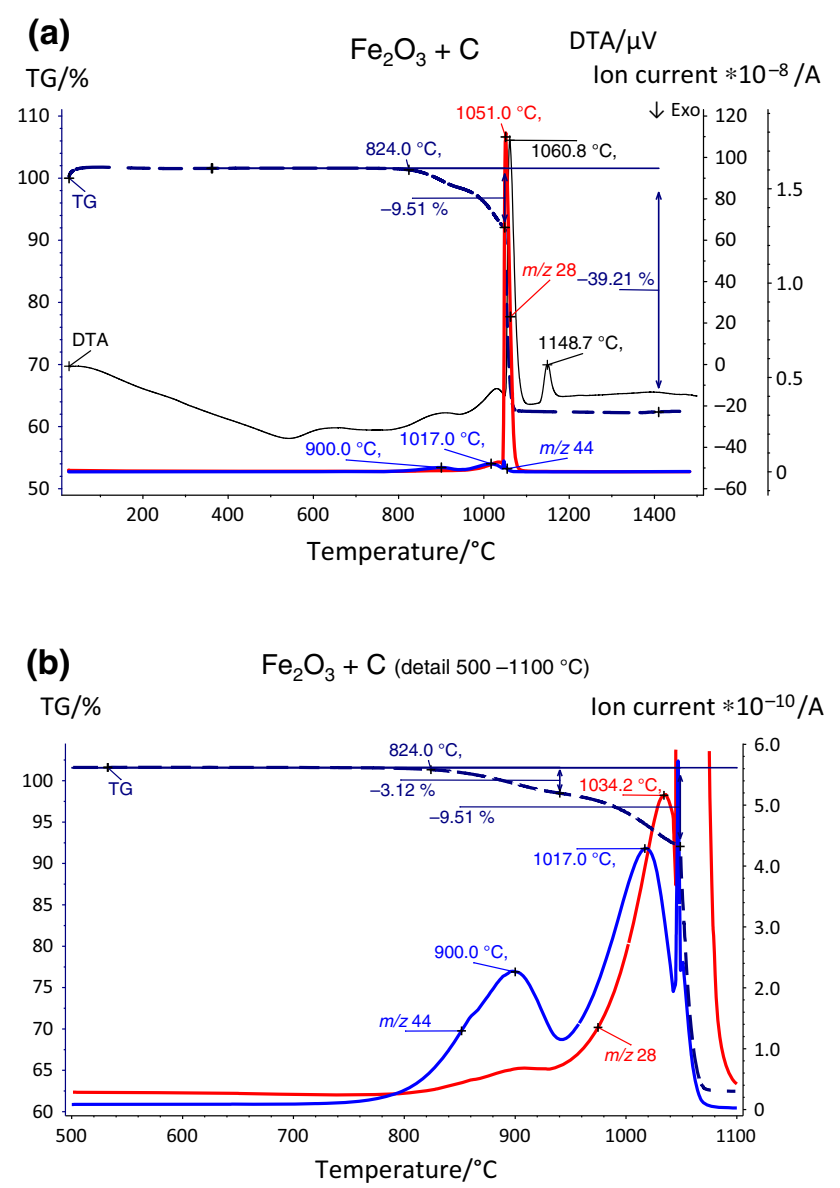

Fig. 1 DTA/TG with $\mathrm{MS}$ for carbothermal reduction of $\mathrm{Fe}_{2} \mathrm{O}_{3}$. a Complete heating stage, $\mathbf{b}$ detail of the temperature range $500-1100{ }^{\circ} \mathrm{C}$

beginning of the next peak in $\mathrm{m} / \mathrm{z}$ 44-is $3.12 \%$, very close to the theoretical mass loss for the reduction $\mathrm{Fe}_{2} \mathrm{O}_{3} \rightarrow \mathrm{Fe}_{3} \mathrm{O}_{4}$ with $\mathrm{CO}_{2}$ as product (3.60\%, Table 5). A second peak in $m / z, 44\left(\mathrm{CO}_{2}\right)$ is observed at $1017{ }^{\circ} \mathrm{C}$, in this case closely followed by the $\mathrm{m} / \mathrm{z} 28$ (CO) signal whose intensity increases and reaches a peak at $1034{ }^{\circ} \mathrm{C}$. The total mass loss in this second reduction stage is $9.51 \%$ which is similar-though lower-to the theoretical mass loss for the partial reduction $\mathrm{Fe}_{2} \mathrm{O}_{3} \rightarrow \mathrm{FeO}$ (see Table 5). Immediately following this second stage, a very strong $\mathrm{m} / \mathrm{z} 28(\mathrm{CO})$ peak is observed, corresponding with an abrupt mass loss (see Fig. 1a) of $39.21 \%$. This mass loss is above the theoretical mass loss expected for the full reduction forming $\mathrm{CO}_{2}$ (32.4 \%, Table 4) and only slightly below the theoretical mass loss for the reaction in which $\mathrm{CO}$ is the product $(41.25 \%$, Table 4). In this third reduction stage, the signal of $\mathrm{m} / \mathrm{z} 28(\mathrm{CO})$ is markedly more intense than the $\mathrm{m} / \mathrm{z} 44$ $\left(\mathrm{CO}_{2}\right)$ signal.

The DTA signal shows endothermic peaks simultaneous to the reduction processes. The endothermic peak observed at $\sim 1149{ }^{\circ} \mathrm{C}$-not followed by a degassing peak-does not indicate a reduction process but rather a melting process of a cast iron with a stoichiometry close to the eutectic (the melting temperature of the eutectic in the $\mathrm{Fe}-\mathrm{C}$ system is $1147^{\circ} \mathrm{C}$ ).

In summary, studies on $\mathrm{Fe}_{2} \mathrm{O}_{3}\left(\mathrm{Fe}^{3+}\right)$ presented in Fig. 1 suggest that the carbothermal reduction of the iron oxide takes place stepwise through the intermediate transformations $\mathrm{Fe}_{2} \mathrm{O}_{3}\left(\mathrm{Fe}^{3+}\right) \rightarrow \mathrm{Fe}_{3} \mathrm{O}_{4}\left(\mathrm{Fe}^{3+}, \mathrm{Fe}^{2+}\right)$ at $\sim 900{ }^{\circ} \mathrm{C}$, $\mathrm{Fe}_{3} \mathrm{O}_{4}\left(\mathrm{Fe}^{3+}, \mathrm{Fe}^{2+}\right) \rightarrow \mathrm{FeO}\left(\mathrm{Fe}^{2+}\right)$ at $\sim 1020-1030^{\circ} \mathrm{C}$ and $\mathrm{FeO}\left(\mathrm{Fe}^{2+}\right) \rightarrow \mathrm{Fe}$ at $\sim 1050{ }^{\circ} \mathrm{C}$. Due to the excess of carbon in the initial mix, the sample melts at temperatures close to the eutectic in the $\mathrm{Fe}-\mathrm{C}$ system $\left(1147^{\circ} \mathrm{C}\right)$.

While the first two reduction processes present a significant formation of $\mathrm{CO}_{2}$, the high temperature reduction $\mathrm{FeO}\left(\mathrm{Fe}^{2+}\right) \rightarrow \mathrm{Fe}$ entails a controlling formation of $\mathrm{CO}$.

The signals observed in the experiments with $\mathrm{SiO}_{2}$ and $\mathrm{Cr}_{2} \mathrm{O}_{3}$ oxides are presented in Fig. 2. Carbothermal reduction of oxides in $\mathrm{SiO}_{2}+\mathrm{C}$ mixes-which should be indicated by the formation of $\mathrm{m} / \mathrm{z} 28$ (CO) — starts only above $1200{ }^{\circ} \mathrm{C}$ and is not completely registered within the temperature range used in this study.

In case of $\mathrm{Cr}_{2} \mathrm{O}_{3}$, only one well-defined $\mathrm{m} / \mathrm{z} 28(\mathrm{CO})$ peak is observed at $\sim 1136{ }^{\circ} \mathrm{C}$ with a flat $\mathrm{m} / \mathrm{z} 44\left(\mathrm{CO}_{2}\right)$ signal. Accordingly, the total mass loss registered in $\mathrm{Cr}_{2} \mathrm{O}_{3}-39.36 \%$-is closer to the theoretical mass loss in the reduction reaction having $\mathrm{CO}$ as product $(41.18 \%$, Table 4) than to the reaction with $\mathrm{CO}_{2}$ as product $(32.35 \%$, Table 4$)$. The results are in very good agreement with previous experiments on reduction of $\mathrm{Cr}$ oxides [11]. The slight mass loss at low temperatures can be related to desorption of water, as indicated by the $\mathrm{m} / \mathrm{z}, 18\left(\mathrm{H}_{2} \mathrm{O}\right)$ signal.

Table 5 Mass losses for the partial reduction of $\mathrm{Fe}_{2} \mathrm{O}_{3}$ with formation of $\mathrm{CO}$ or $\mathrm{CO}_{2}$

\begin{tabular}{llr}
\hline Transformation & Reaction & Theoretical mass loss/\% \\
\hline $\mathrm{Fe}_{2} \mathrm{O}_{3} \rightarrow \mathrm{Fe}_{3} \mathrm{O}_{4}$ & $\mathrm{Fe}_{2} \mathrm{O}_{3}+11 / 3 \mathrm{C}=2 / 3 \mathrm{Fe}_{3} \mathrm{O}_{4}+7 / 2 \mathrm{C}+1 / 6 \mathrm{CO}_{2}$ & 3.60 \\
& $\mathrm{Fe}_{2} \mathrm{O}_{3}+11 / 3 \mathrm{C}=2 / 3 \mathrm{Fe}_{3} \mathrm{O}_{4}+10 / 3 \mathrm{C}+1 / 3 \mathrm{CO}$ & 4.58 \\
$\mathrm{Fe}_{2} \mathrm{O}_{3} \rightarrow \mathrm{FeO}$ & $\mathrm{Fe}_{2} \mathrm{O}_{3}+11 / 3 \mathrm{C}=2 \mathrm{FeO}+19 / 6 \mathrm{C}+1 / 2 \mathrm{CO}_{2}$ & 10.80 \\
& $\mathrm{Fe}_{2} \mathrm{O}_{3}+11 / 3 \mathrm{C}=\mathrm{FeO}+5 / 3 \mathrm{C}+\mathrm{CO}$ & 13.75 \\
\hline
\end{tabular}



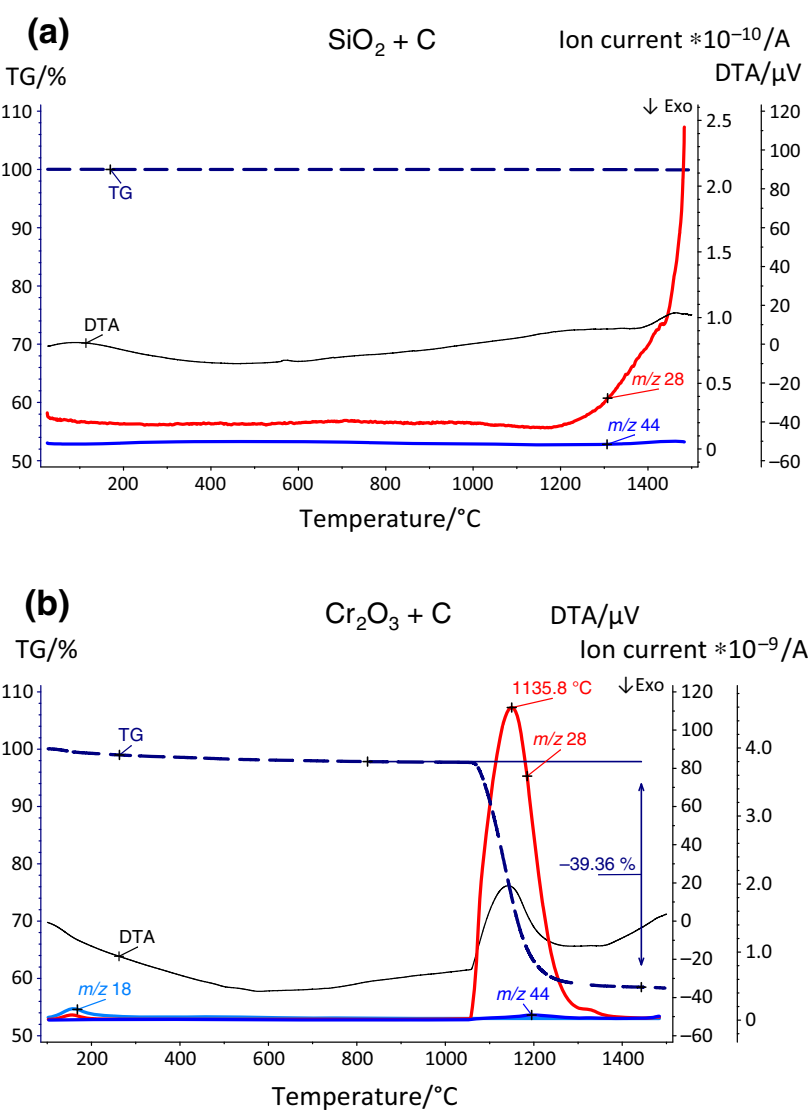

Fig. 2 DTA/TG with MS for carbothermal reduction of a $\mathrm{SiO}_{2}$ and b $\mathrm{Cr}_{2} \mathrm{O}_{3}$

Reduction of $\mathrm{MnO}_{2}$ takes place in three stages, well defined in the thermogravimetry curve (see Fig. 3a). The first reduction stage is accompanied by an $\mathrm{m} / \mathrm{z}, 44\left(\mathrm{CO}_{2}\right)$ peak at $611{ }^{\circ} \mathrm{C}$, and the mass loss associated is $\sim 8.94 \%$, in excellent agreement with the theoretical mass loss expected for the partial reduction $\mathrm{MnO}_{2} \rightarrow \mathrm{Mn}_{2} \mathrm{O}_{3}$ with formation of $\mathrm{CO}_{2}(8.95 \%$, Table 6). This first reduction stage presents a simultaneous exothermic peak in the DTA signal, in contrast with the reduction processes previously shown, which produced an endothermic reaction. Calculation of the enthalpy change- $\Delta H-$ for different reduction reactions was carried out using the software HSC Chemistry 9, and the results are represented in Fig. 3b. It should be noted here that the $\Delta H$ of these reaction is not constant with the temperature. The flat appearance of the lines is only due to the scale selected to represent the enthalpy of all the reactions. While the partial dissociation of the oxide $\mathrm{MnO}_{2} \rightarrow \mathrm{Mn}_{2} \mathrm{O}_{3}$ (reaction 3 in Fig. 3b) would be endothermic, the global reaction for the partial carbothermal reduction $\mathrm{MnO}_{2} \rightarrow \mathrm{Mn}_{2} \mathrm{O}_{3}$ with formation of $\mathrm{CO}$ (reaction 2 in Fig. 3b) or $\mathrm{CO}_{2}$ (reaction 1 in Fig. 3b) is indeed exothermic, especially in the latter case.

The second reduction stage is also defined by an $\mathrm{m} / z 44$ $\left(\mathrm{CO}_{2}\right)$ peak, and the total mass loss associated $18.33 \%$ is
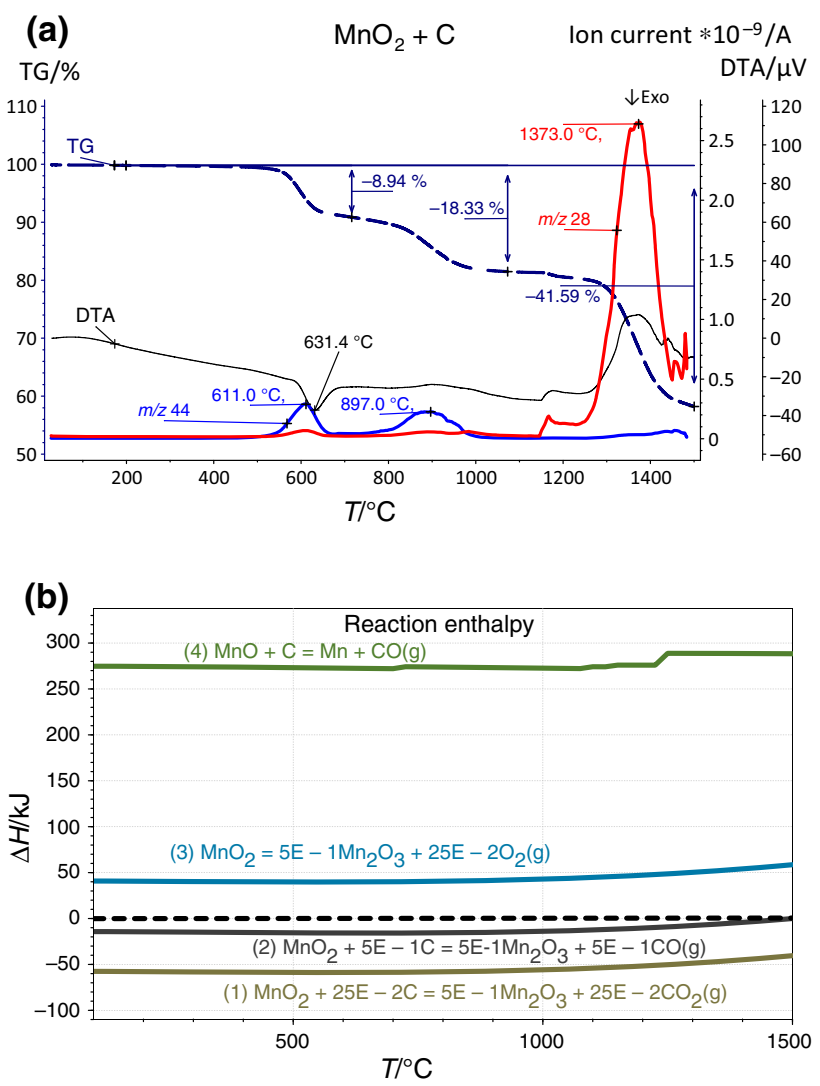

Fig. 3 a DTA/TG with MS for carbothermal reduction of $\mathrm{MnO}_{2}$ and b enthalpy versus $T$ for different reduction reactions. Calculations performed using the software HSC Chemistry version 4.1

very close to the theoretical mass loss expected for the partial reduction $\mathrm{MnO}_{2} \rightarrow \mathrm{MnO}$ with formation of $\mathrm{CO}_{2}$ (17.89, Table 6).

The final reduction stage should then correspond to the reduction $\mathrm{MnO} \rightarrow \mathrm{Mn}$ and takes place with a significant formation of $\mathrm{m} 28$ (CO) at $1373{ }^{\circ} \mathrm{C}$. The $\mathrm{m} 28$ (CO) peak occurs simultaneously with an intense endothermic DTA peak, which is in agreement with the high and positive enthalpy change obtained for this reaction in the theoretical calculations (reaction 4 in Fig. 3b).

In summary, studies on $\mathrm{MnO}_{2}$ suggest that the partial reduction $\mathrm{MnO}_{2}\left(\mathrm{Mn}^{4+}\right) \rightarrow \mathrm{MnO}\left(\mathrm{Mn}^{2+}\right)$ takes place at temperatures below $1000{ }^{\circ} \mathrm{C}$ and is characterized by two processes in which $\mathrm{CO}_{2}$ is the main reaction product. However, the reduction $\mathrm{MnO}\left(\mathrm{Mn}^{2+}\right) \rightarrow \mathrm{Mn}$ takes place at considerably higher temperatures $\left(\sim 1373{ }^{\circ} \mathrm{C}\right)$ and in this case $\mathrm{CO}$ is the main reaction product.

For the sintering of steels containing $\mathrm{Mn}$ carriers, evaporation of $\mathrm{Mn}$ and subsequent condensation on the surrounding Fe particles is a widely studied phenomenon [12-14]. Due to the ability of Mn to sublimate at temperatures above $\sim 700{ }^{\circ} \mathrm{C}, \mathrm{Mn}$-containing oxides are typically observed on the grain boundaries of the iron base particles, 
Table 6 Mass losses for the partial reduction of $\mathrm{MnO}_{2}$ with the formation of $\mathrm{CO}_{2}$

\begin{tabular}{lll}
\hline Transformation & Reaction & $\begin{array}{l}\text { Theoretical } \\
\text { mass } \\
\text { loss } / \%\end{array}$ \\
\hline $\mathrm{MnO}_{2} \rightarrow \mathrm{Mn}_{2} \mathrm{O}_{3}$ & $\begin{array}{c}\mathrm{MnO}_{2}+3 \mathrm{C}=1 / 2 \mathrm{Mn}_{2} \mathrm{O}_{3} \\
+11 / 4 \mathrm{C}+1 / 4 \mathrm{CO}_{2}\end{array}$ & 8.95 \\
$\mathrm{MnO}_{2} \rightarrow \mathrm{Mn}_{3} \mathrm{O}_{4}$ & $\begin{array}{c}\mathrm{MnO}_{2}+3 \mathrm{C}=1 / 3 \mathrm{Mn}_{3} \mathrm{O}_{4} \\
+8 / 3 \mathrm{C}+1 / 3 \mathrm{CO}_{2}\end{array}$ \\
$\mathrm{MnO}_{2} \rightarrow \mathrm{MnO}$ & $\begin{array}{c}\mathrm{MnO}_{2}+3 \mathrm{C}=\mathrm{MnO}^{2} \\
+5 / 2 \mathrm{C}+1 / 2 \mathrm{CO}_{2}\end{array}$ \\
& & 11.93 \\
\end{tabular}

causing an important damage on the mechanical performance $[14,15]$. However, it is difficult to determine whether the oxides formed on grain boundaries are $\mathrm{Fe}-\mathrm{Mn}$ mixed oxides or more stable Mn oxides. In order to identify its characteristic reduction temperatures, the carbothermal reduction of $\mathrm{Fe}_{2} \mathrm{MnO}_{4}$ spinel oxides was analyzed in this study (Fig. 4a).

In Fig. 4a, the initial mass loss at temperatures below $400{ }^{\circ} \mathrm{C}$ is related to desorption of water, as indicated by the $\mathrm{m} 18\left(\mathrm{H}_{2} \mathrm{O}\right)$ peak. The reduction processes are initially
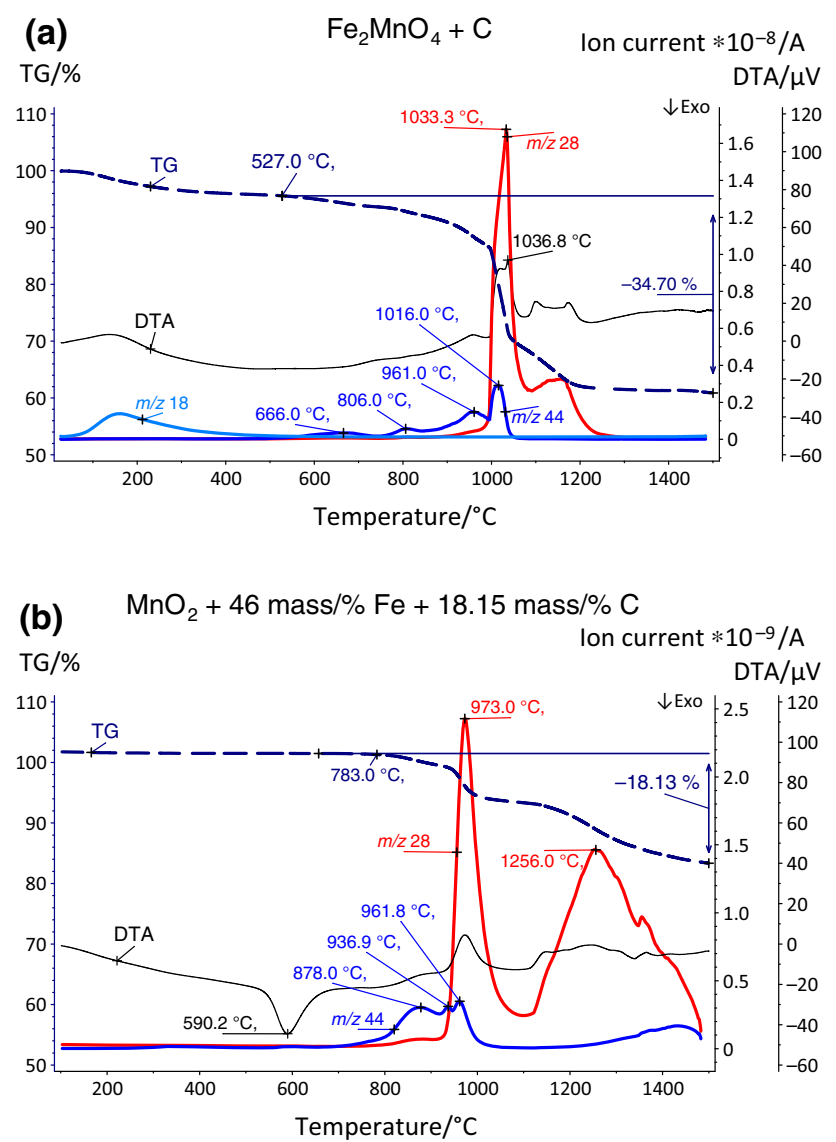

Fig. 4 DTA/TG with $\mathrm{MS}$ for carbothermal reduction of a $\mathrm{Fe}_{2}$ $\mathrm{MnO}_{4}+\mathrm{C}$ and $\mathbf{b} \mathrm{MnO}_{2}+\mathrm{Fe}+\mathrm{C}$ linked with the formation of $\mathrm{m} / z 44\left(\mathrm{CO}_{2}\right)$, which presents peaks at 666,806 and $961{ }^{\circ} \mathrm{C}$. The main mass loss occurs at higher temperatures with a very intense $\mathrm{m} 28(\mathrm{CO})$ peak at $1033{ }^{\circ} \mathrm{C}$ and a lower peak of $\mathrm{m} 44\left(\mathrm{CO}_{2}\right)$ at $1016{ }^{\circ} \mathrm{C}$. The peak at $1033{ }^{\circ} \mathrm{C}$ corresponds in temperature with that of the reduction of $\mathrm{Fe}_{3} \mathrm{O}_{4}\left(\mathrm{Fe}^{3+}, \mathrm{Fe}^{2+}\right) \rightarrow \mathrm{FeO}\left(\mathrm{Fe}^{2+}\right)$ at $\sim 1034{ }^{\circ} \mathrm{C}$ (Fig. 1), which suggest that this stage represents a reduction in the $\mathrm{Fe}$ part of the spinel oxide. Complete reduction is observed at temperatures below $1200{ }^{\circ} \mathrm{C}$, with a total mass loss of $34.70 \%$ which is below the value for the reaction with formation of $\mathrm{CO}(37.51 \%$, Table 4$)$ and well above the value for formation of $\mathrm{CO}_{2}(18.75 \%$, Table 4).

Considering the different oxygen affinity of $\mathrm{Fe}$ and $\mathrm{Mn}$, a stepwise reduction of $\mathrm{Fe}_{2} \mathrm{MnO}_{4}$ with the formation of $\mathrm{MnO}$ at an intermediate stage would be expected. However, during the reduction of $\mathrm{Fe}_{2} \mathrm{MnO}_{4}$ (Fig. 4a), the peak observed at $1373{ }^{\circ} \mathrm{C}$ in Fig. 3-indicating the reduction $\mathrm{MnO} \rightarrow \mathrm{Mn}-\mathrm{is}$ not registered. The reason might be that the reduction temperature of $\mathrm{MnO} \rightarrow \mathrm{Mn}$ is decreased by the presence of metallic iron, the driving force being the lower chemical activity of Mn when it is dissolved in Fe. To investigate this effect, reduction of a mix containing $\mathrm{MnO}_{2}$ and $\mathrm{Fe}$ powder was analyzed (Fig. $4 \mathrm{~b}$ ). The stoichiometry of this mix was calculated to provide the same $\mathrm{Fe} / \mathrm{Mn}$ ratio as that of the $\mathrm{Fe}_{2} \mathrm{MnO}_{4}$ oxide.

As shown in Fig. 3, reduction of $\mathrm{MnO}_{2}$ presents mass losses at $\sim 610$ and $\sim 900{ }^{\circ} \mathrm{C}$ with formation of $\mathrm{m} / \mathrm{z}, 44$ $\left(\mathrm{CO}_{2}\right)$. In mixes containing $\mathrm{MnO}_{2}$ and $\mathrm{Fe}$ powder, neither the mass loss nor the formation of $\mathrm{m} / \mathrm{z}, 44\left(\mathrm{CO}_{2}\right)$ is observed. However, the exothermic peak indicating the transformation $\mathrm{MnO}_{2} \rightarrow \mathrm{Mn}_{2} \mathrm{O}_{3}$ is clearly present in the DTA signal. This suggests that the partial reduction $\mathrm{MnO}_{2} \rightarrow \mathrm{Mn}_{2} \mathrm{O}_{3}$ is actually taking place, but the reaction product (in this case mainly $\mathrm{CO}_{2}$ ) immediately reacts oxidizing the $\mathrm{Fe}$ particles. Thus, partial reduction $\mathrm{MnO}_{2} \rightarrow \mathrm{Mn}_{2} \mathrm{O}_{3}$ causes oxidation of the iron particles and this explains the absence of the $\mathrm{CO}_{2}$ peak, as well as the flat TG signal. The oxygen is simply transferred between the different powder particles. The first mass loss is registered at $\sim 780^{\circ} \mathrm{C}$, when the carbothermal reduction of $\mathrm{Fe}$ oxides is thermodynamically possible.

The first reduction stages in mixes $\mathrm{MnO}_{2}+\mathrm{Fe}$ occur with formation of $\mathrm{m} / \mathrm{z} 44\left(\mathrm{CO}_{2}\right)$ peaks at $\sim 878,937$, $962{ }^{\circ} \mathrm{C}$ and with an intense $\mathrm{m} / \mathrm{z}, 28(\mathrm{CO})$ peak at $\sim 973{ }^{\circ} \mathrm{C}$. These lower temperature processes are most likely related to the reduction of $\mathrm{Fe}$ oxides and with the transformation from $\mathrm{MnO}_{2} \rightarrow \mathrm{MnO}$, both of which were observed in this same range of temperature (see Figs. 1, 3).

The second reduction stage is represented by a broad $\mathrm{m} / \mathrm{z} 28$ (CO) peak and a mass loss starting at $\sim 1100{ }^{\circ} \mathrm{C}$ and with a maximum in the $\mathrm{m} / \mathrm{z} 28(\mathrm{CO})$ peak at $1256{ }^{\circ} \mathrm{C}$. The broad $\mathrm{m} / \mathrm{z} 28(\mathrm{CO})$ peak covers the temperature at 
(a)

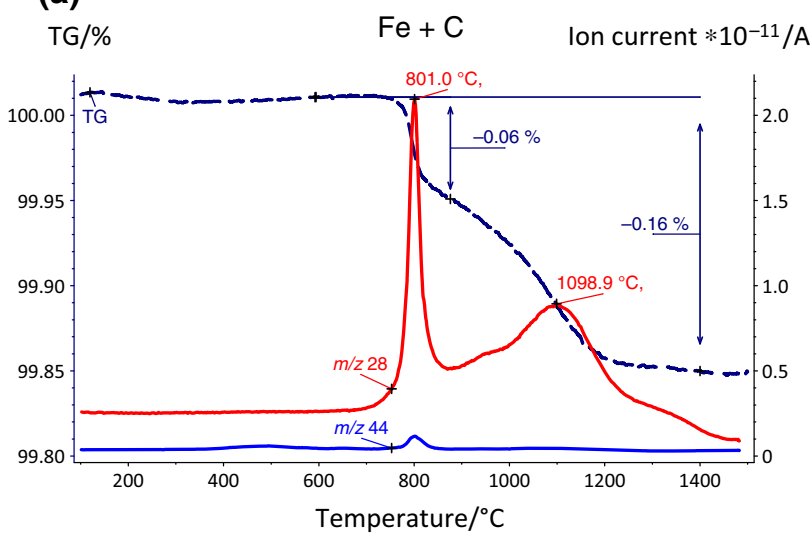

(c) TG/\%

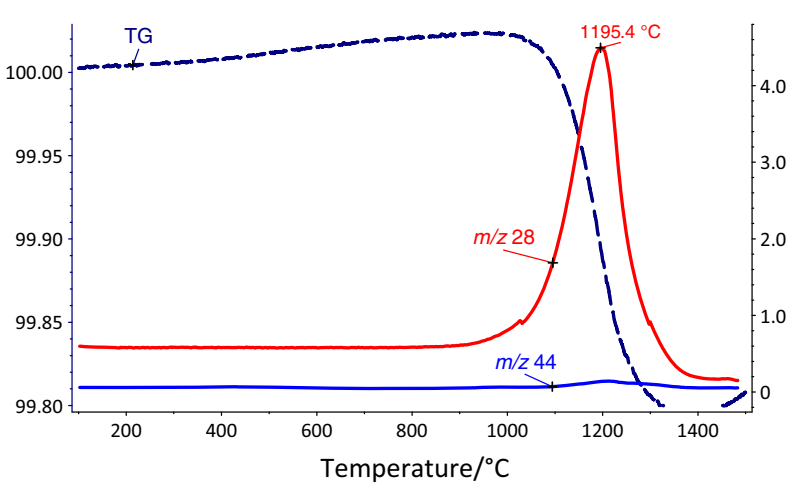

(b)

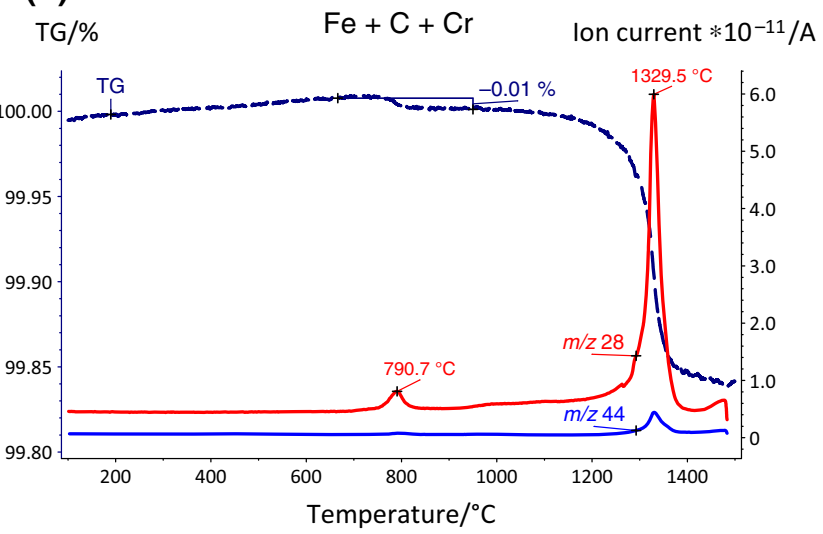

(d)

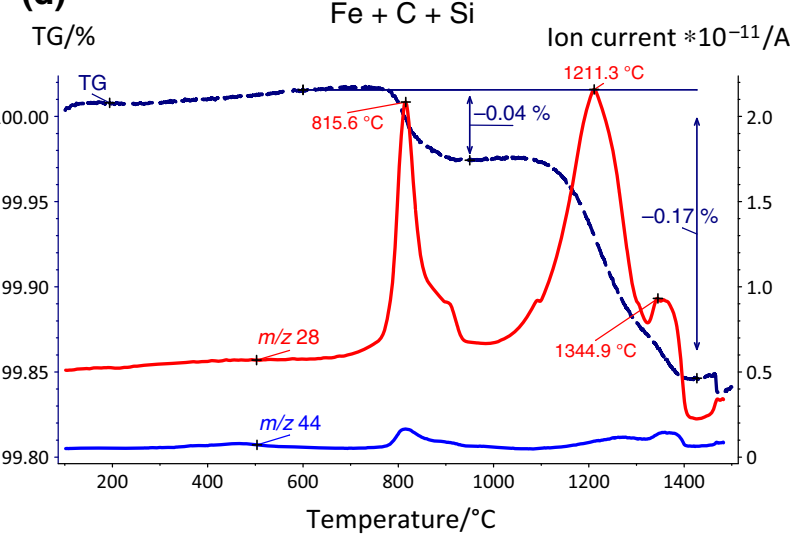

Fig. $5 \mathrm{TG}$ with MS for the carbothermal reduction in mixes: a Fe +0.5 mass $/ \% \mathrm{C}, \mathbf{b} \mathrm{Fe}+0.5$ mass $/ \% \mathrm{C}+4 \mathrm{mass} / \% \mathrm{Cr}$, c Fe $+0.5 \mathrm{mass} / \%$ $\mathrm{C}+4$ mass $/ \% \mathrm{Mn}, \mathbf{d} \mathrm{Fe}+0.5$ mass $/ \% \mathrm{C}+4$ mass $/ \% \mathrm{Si}$

which the $\mathrm{m} 28(\mathrm{CO})$ peak indicating the reduction $\mathrm{MnO} \rightarrow \mathrm{Mn}$ was observed in $\mathrm{MnO}_{2}+\mathrm{C}$ mixes $\left(\sim 1373{ }^{\circ} \mathrm{C}\right)$. As observed in Fig. 3, $\mathrm{MnO}_{2}$ is reduced to $\mathrm{MnO}$ at temperatures below $1000{ }^{\circ} \mathrm{C}$, which suggest that this broad peak could correspond with the reduction of $\mathrm{MnO}$ oxides-enhanced by the presence of metallic iron-and/or the reduction of some $\mathrm{Fe}-\mathrm{Mn}$ oxides such an (Fe, $\mathrm{Mn})_{3} \mathrm{O}_{4}$ spinel rich in $\mathrm{Mn}$. The results obtained for $\mathrm{MnO}_{2}+\mathrm{Fe}$ mixes corroborate that the carbothermal reduction of $\mathrm{Mn}$ oxides is modified by the presence of metallic Fe.

\section{Oxidation/reduction phenomena on steel powder mixes containing additions of different oxidation- sensitive elements}

Thermal analysis techniques have been proved to be very efficient tools for studying the oxidation/reduction phenomena taking place when sintering steel powders $[1,2,9,16,17]$. Thermogravimetry curve and $\mathrm{m} 28$ (CO) signal-which is in all experiments considerably more intense than m44
$\left(\mathrm{CO}_{2}\right)$ - are shown in Fig. 5a for mixes containing water-atomized metallic Fe with 0.5 mass $/ \%$ graphite.

The surface of different Fe-based atomized powders has been characterized in several studies by Nyborg et al. using surface sensitive analysis techniques [18-21]. Water-atomized powders are typically covered by a homogeneous iron oxide layer formed by $\mathrm{Fe}_{2} \mathrm{O}_{3}$ with a thickness of around $6-8 \mathrm{~nm}$ and disperse particulate oxides of a higher stability (mainly $\mathrm{Cr}-, \mathrm{Mn}$ - and Si-containing oxides) with an average size of $200 \mathrm{~nm}$ [22]. These findings are in excellent agreement with the reduction processes observed by thermal analysis techniques (see Fig. 5a), which show two main reduction stages: the first one at $\sim 800{ }^{\circ} \mathrm{C}$ corresponding with the reduction of the iron oxide layer covering most of the surface of the powder particles and the second one at $\sim 1100{ }^{\circ} \mathrm{C}$ indicating the reduction of more stable oxides, or internal oxides that need higher temperatures to diffuse to the powder surface $[1,2]$.

Comparing these results with those obtained for the reduction of $\mathrm{Fe}_{2} \mathrm{O}_{3}$ oxides, it is evident that the reduction of iron oxides takes place at lower temperatures in metallic 
powders. This suggests that the reduction process is affected by the fact that the oxide layer is present on the surface of metallic particles. When pure oxides are reduced, the nucleation of metallic particles might require an activation energy that is reduced when this oxide is present in the form of a thin layer covering a metallic particle.

It is also noteworthy the fact that the reduction at $800{ }^{\circ} \mathrm{C}$ is accompanied by an intense peak in the $\mathrm{m} / \mathrm{z} 28$ (CO) signal, with a negligible signal of $\mathrm{m} / z, 44\left(\mathrm{CO}_{2}\right)$. Traditionally, the indirect reaction with formation of $\mathrm{CO}_{2}$ (Eq. 2) has been considered to be the main reduction mechanism at this stage. The fact that the most intense signal registered during reduction was $\mathrm{m} / \mathrm{z} 28$ (CO) was assumed to be a consequence of the immediate recombination of $\mathrm{CO}_{2}$ to $\mathrm{CO}$ through the Boudouard equilibrium (Eq. 3). However, if this immediate recombination of $\mathrm{CO}_{2}$ was possible at $\sim 800{ }^{\circ} \mathrm{C}$, also a $\mathrm{CO}$ peak-instead of $\mathrm{CO}_{2}$ - should be observed at this range of temperatures in the experiments with oxides presented in Figs. 3 and 4.

The experiments with $\mathrm{MnO}_{2}$ and $\mathrm{Fe}_{2} \mathrm{O}_{3}$ oxides show that it is the last reduction stage (the transformation to the metallic phase) the one that is accompanied by an intense CO signal. This suggests that the presence of a metallic phase in contact with the oxide is enhancing the direct carbothermal mechanism. A possible explanation for this could be given through the effect of the dissolution of carbon on the metallic phases. Once carbon is dissolved in the metallic matrix in contact with the oxide, its availability is higher than when it is in the form of graphite particles. Thus, dissolution of carbon (at approximately $700-800{ }^{\circ} \mathrm{C}$ ) could be the limiting step for the activation of the direct reduction mechanism in metallic Fe powders. In contrast, during the reduction of pure oxides, it is the presence of metallic phases - in which carbon can be dissolved-the limiting step for the activation of the direct reduction mechanism.

Figure $5 \mathrm{~b}-\mathrm{d}$ represents the reduction reactions when these $\mathrm{Fe}-\mathrm{C}$ mixes are modified with the addition of small amounts (4 mass/\%) of alloying elements with a high affinity for oxygen. The most characteristic feature observed in steels containing $\mathrm{Cr}$ (Fig. 5b) and Mn (Fig. 5c) is the absence-or drastic reduction-of the $\mathrm{m} / \mathrm{z} 28$ (CO) peak corresponding to the reduction of the iron oxide layer. Furthermore, this phenomenon is accompanied by a constant mass in the thermogravimetry curve. This is can be explained by the fact that the oxygen-sensitive alloying particles can act as oxygen getters. The reaction products from the reduction of the iron oxide layers $\left(\mathrm{CO}\right.$ and $\left.\mathrm{CO}_{2}\right)$ are an oxidizing agent for the particles with a higher oxygen affinity. Thus, the oxygen is simply transferredthrough the gaseous species $\mathrm{CO}$ and $\mathrm{CO}_{2}$-from the easily reducible $\mathrm{Fe}$ oxide covering the $\mathrm{Fe}$ base powders to the oxygen-sensitive alloying particles. This phenomenon has been identified as an "internal-gettering" effect caused by the presence of elements with a high oxygen affinity and has been described in detail in $[9,23]$.

This oxygen-gettering effect is less intense in the case of mixes with Si powders (see Fig. 5d), most likely because of the protective character of the oxide covering the surface of $\mathrm{Si}$ particles. As shown in Fig. $2 \mathrm{a}, \mathrm{SiO}_{2}$ presents very high stability, and signs of reduction are only observed at temperatures above $1200{ }^{\circ} \mathrm{C}$. However, at high temperatures, cracking of the protective oxide layer covering the $\mathrm{Si}$ particles can give rise to an oxygen transfer to the Si particles which is evidenced by the constant mass in the thermogravimetry curve at temperatures above $900{ }^{\circ} \mathrm{C}$ (Fig. 5d). The reduction processes are reactivated at higher temperatures and are represented by a broad peak with a maximum at $1210{ }^{\circ} \mathrm{C}$. The highest relative intensity of this second reduction stage (compared to that observed in $\mathrm{Fe}+\mathrm{C}$ mixes) is due to the presence of higher amounts of oxides with a higher stability.

Mn seems to act as a very effective oxygen getter, eliminating completely any signs of reduction of the iron oxides at $\sim 800{ }^{\circ} \mathrm{C}$. The high temperature reduction produces a broad $\mathrm{m} 28(\mathrm{CO})$ peak at $\sim 1200{ }^{\circ} \mathrm{C}$. A comparison of this $\mathrm{m} 28(\mathrm{CO})$ peak with the $\mathrm{m} 28(\mathrm{CO})$ peaks observed during the reduction experiments with Mn oxides (Figs. 3, 4) is presented in Fig. 6.

The reduction of oxides in $\mathrm{Fe}+\mathrm{Mn}+\mathrm{C}$ mixes falls into an intermediate temperature range: between the low temperature reduction in mixes $\mathrm{MnO}_{2}+\mathrm{Fe}+\mathrm{C}$ or $\mathrm{Fe}_{2}$ $\mathrm{MnO}_{4}+\mathrm{C}$ and the high temperature reduction in $\mathrm{MnO}_{2}+\mathrm{C}$ mixes (see Fig. 6). The high temperature reduction in $\mathrm{MnO}_{2}+\mathrm{C}$ mixes is associated with the reduction of $\mathrm{MnO}$, which, as the most stable Mn oxide, is generated from $\mathrm{MnO}_{2}$ through several earlier reduction stages. Thus, if $\mathrm{MnO}$ oxides are formed when sintering $\mathrm{Fe}-$ $\mathrm{Mn}-\mathrm{C}$ steels, one would expect to find a reduction peak at high temperatures $\sim 1370{ }^{\circ} \mathrm{C}$, but instead, most of the reduction is registered at $\sim 1200{ }^{\circ} \mathrm{C}$. There are two phenomena that could give rise to this effect. Significant formation of mixed $\mathrm{Fe}-\mathrm{Mn}$ oxides (instead of $\mathrm{MnO}$ ) on the surface of the $\mathrm{Fe}$ base particles as a consequence of $\mathrm{Mn}$ evaporation-condensation processes could shift the reduction peaks to temperatures close to those observed in the reduction of $\mathrm{Fe}_{2} \mathrm{MnO}_{4}$ spinels. Also, even if the more stable $\mathrm{MnO}$ oxides are formed, their reduction can be enhanced when they are in contact with metallic $\mathrm{Fe}$, since the chemical activity of $\mathrm{Mn}$ is lowered when it is dissolved in $\mathrm{Fe}$ (this being the driving force for the reduction).

$\mathrm{Cr}$ also seems to be a very effective oxygen-gettering agent in the range of temperatures where the reduction of iron oxide layers takes place $\left(\sim 800{ }^{\circ} \mathrm{C}\right)$. In this case, the $\mathrm{m} / \mathrm{z} 28$ (CO) peak and the mass loss characterizing the 


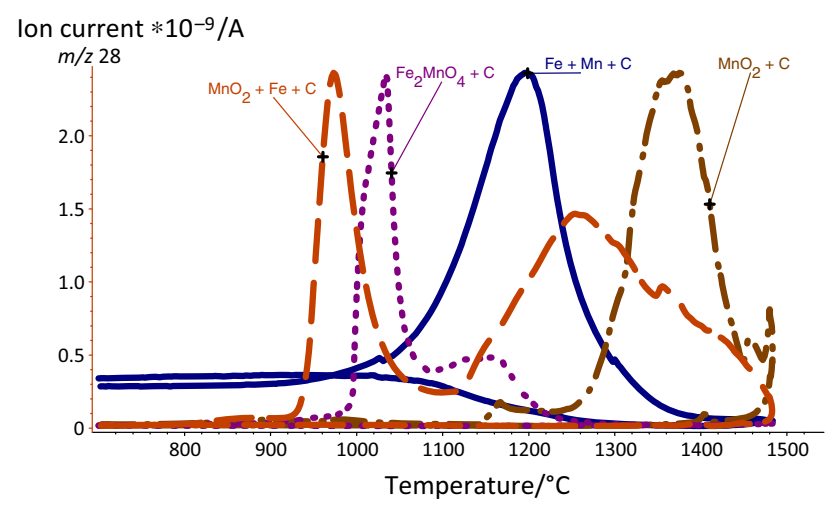

Fig. 6 Degassing curve $\mathrm{m} 28(\mathrm{CO})$ for the experiments carried out in mixes $\mathrm{MnO}_{2}+\mathrm{C}, \mathrm{Fe}_{2} \mathrm{MnO}_{4}+\mathrm{C}, \mathrm{Fe}+\mathrm{Mn}+\mathrm{C}, \mathrm{MnO}_{2}+\mathrm{C}$

reduction are shifted to very high temperatures $\left(\sim 1330^{\circ} \mathrm{C}\right)$, which are in fact much higher than the temperatures required for the carbothermal reduction of $\mathrm{Cr}_{2} \mathrm{O}_{3}$ oxides (see Fig. 2b). The excessively high temperature of this peak (higher than the temperature needed to reduce the more stable oxide possible in this system), together with the sharp shape of the $\mathrm{m} 28(\mathrm{CO})$ peak and the abrupt mass change, suggests that reduction is activated by the formation of a liquid phase.

When the oxygen-sensitive alloying elements are introduced in the form of a master alloy powder, the oxygen-gettering effect is reduced (see Fig. 7a, b). In case of MA1 and MA2, the $m / z 28$ (CO) peak is observed together with a mass loss at $\sim 730{ }^{\circ} \mathrm{C}$. However, the relative intensity of the $\mathrm{m} 28$ (CO) peak as well as the mass loss observed in this first stage of reduction is still considerably lower than in $\mathrm{Fe}-0.5^{\circ} \mathrm{C}$ mixes. When high amounts of alloying elements with high oxygen affinity are introduced in the master alloy (as is the case of MA3 in Fig. 7c), the first stage of reduction is almost completely eliminated, and the reduction processes are shifted to higher temperatures, presenting only one broad peak at $\sim 1200{ }^{\circ} \mathrm{C}$. This latter behavior is similar to that observed with $\mathrm{Mn}$ powders admixed to $\mathrm{Fe}-\mathrm{C}$. In case of MA3, the more significant shift of the reduction processes-compared to MA1 and MA2-is most likely a consequence of the addition of 15 mass $/ \% \mathrm{Cr}$ in the master alloy composition, as $\mathrm{Cr}$ showed to be an active oxygen getter.
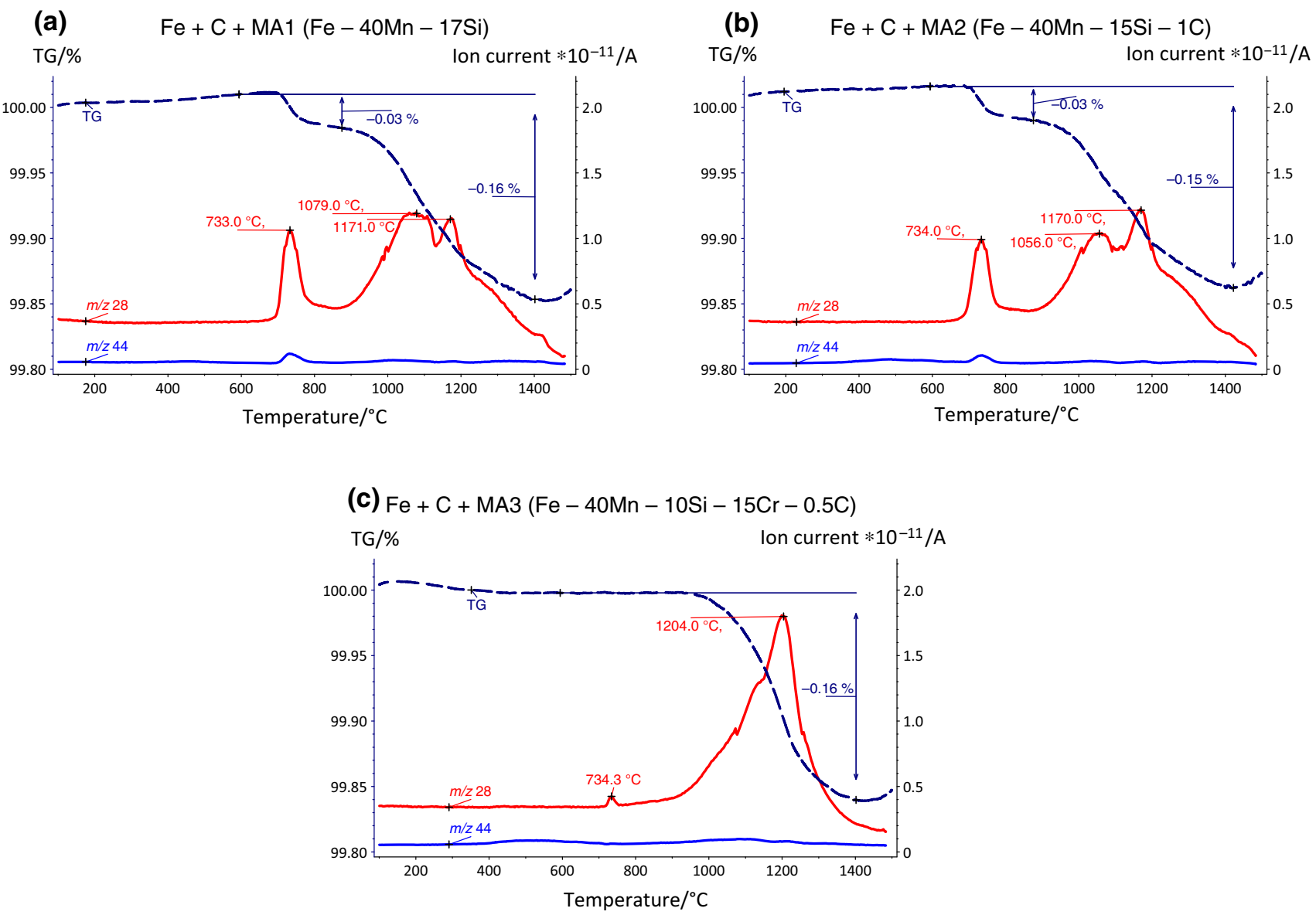

Fig. 7 TG with MS for the carbothermal reduction in mixes: a $\mathrm{Fe}+0.5$ mass $/ \% \mathrm{C}+4$ mass $/ \% \mathrm{MA} 1(\mathrm{Fe}-40 \mathrm{Mn}-17 \mathrm{Si}), \mathbf{b} \mathrm{Fe}+0.5 \mathrm{mass} / \%$ $\mathrm{C}+4$ mass $/ \%$ MA2 (Fe-40Mn-15Si-1C), c Fe +0.5 mass $/ \% \mathrm{C}+4$ mass $/ \%$ MA3 (Fe-40Mn-10Si-15Cr-0.5C) 
In case of MA1 and MA2, the reduction stages at high temperatures present two well-differentiated peaks related to the reduction of oxides with different thermodynamic stability. The compositional differences between MA1 and MA2 (MA2 contains carbon and presents slightly lower amount of $\mathrm{Si}$ ) do not seem to play a significant role in the reduction processes, as they are most likely dominated by the high Mn content in the master alloy.

\section{Microscopic examination of steels sintered at $900{ }^{\circ} \mathrm{C}$ in Ar atmosphere}

Thermal analysis has shown how small additions of oxygen-sensitive alloying elements to $\mathrm{Fe}-\mathrm{C}$ based steels modify strongly the typical reduction processes. Powder particles of elements with a high oxygen affinity are oxidized by the gaseous products of the reduction of the surface iron oxides. It is, however, important to analyze the location and morphology of the oxides formed, in order to predict the possible effect on further development of the microstructure and on the final mechanical properties. Therefore, green compacts containing additions of either $\mathrm{Cr}, \mathrm{Mn}, \mathrm{Si}$ or master alloys powders were pressed at $600 \mathrm{MPa}$ and sintered for $1 \mathrm{~h}$ at $900{ }^{\circ} \mathrm{C}$ in protective atmosphere, Ar. The sintering temperature- $900{ }^{\circ} \mathrm{C}$ - was selected for being the temperature at which most of the mixes studied presented at least slight indications of this oxygen-gettering effect.

Both the cross section and the fracture surfaces of samples containing additions of $\mathrm{Cr}, \mathrm{Mn}$ and $\mathrm{Si}$ are presented in Fig. 8. The chemical composition in different areas has been analyzed with an EDS detector. The numbers indicating the chemical compositions are to be interpreted only qualitatively, as quantitative evaluation is not possible. Images of the sample containing admixed $\mathrm{Cr}$ (Fig. 8a) show the formation of a layer with increased $\mathrm{C}$ content on the interface between $\mathrm{Cr}$ and $\mathrm{Fe}$ particles, which suggest the formation of $\mathrm{Fe}-\mathrm{Cr}$ carbides on the interface. Formation of such carbides has been already reported during sintering of steels containing admixed Cr [24, 25]. As can be observed on the fracture surface, in Fig. 8a, the oxides are concentrated on the surface of the $\mathrm{Cr}$ particles, enclosed by the carbide shell formed on the interface. This explains the high temperature of the reduction peak observed in Fig. 5b. Since the oxides are enclosed inside the carbide layer, reduction can only take place after melting of these carbides at $\sim 1330{ }^{\circ} \mathrm{C}$.

Line scanning on the cross section of samples containing Mn (Fig. 8b left) shows a diffusion profile suggesting that in this case no new phases are formed on the interface between $\mathrm{Fe}$ and $\mathrm{Mn}$ particles. The image of the fracture surface-in Fig. 8b right_-presents the area between Mn particles and Fe base powders. Areas with a high oxygen content were detected by EDS analyses (see area 2 and area 3 in Fig. 8b right). The oxides seem to be present in the form of particulates both on the surface of the Mn particles and on the surface of the $\mathrm{Fe}$ base powder, as previously reported by Hryha et al. [14, 15, 26]. It is not possible to identify using EDS analysis whether these are Mn oxides or mixed Fe-Mn oxides. The fact that these oxides adhere to the Fe base particles supports the hypothesis suggested by thermal analysis in Fig. 5c. The reduction of Mn oxides might be enhanced by the fact that these oxides are present on the surface of a metallic iron base particle. The formation of $\mathrm{Mn}$ oxides on grain boundaries of the surrounding $\mathrm{Fe}$ base particles has a negative effect. It is responsible for the degradation of mechanical properties, promoting brittle fracture by intergranular failure [14, 15, 26].

In case of steels containing $\mathrm{Si}$, an intermetallic compound is clearly formed on the interface. Its composition is very stable (75 at.\% Fe, 25 at.\% Si, Fig. 8c left) and matches the composition of the $\mathrm{Fe}_{3} \mathrm{Si}$ intermetallic phase. Formation of stoichiometric $\mathrm{Fe}_{3} \mathrm{Si}$ has been previously reported for $\mathrm{Fe} / \mathrm{Si}$ diffusion couples annealed at $700{ }^{\circ} \mathrm{C}$ [27]. No significant amounts of oxides are observed at this temperature, probably because $900{ }^{\circ} \mathrm{C}$ is only at the beginning of the range in which the oxygen-gettering effect is observed in Fe-C-Si mixes (see Fig. 5c). High oxygen content is detected in some areas of the Fe base particles that present flaky features on the surface (area 1 in Fig. 8c right), while the iron surfaces located far from the Si particles present a much cleaner appearance, and apparently no presence of oxides (area 4 in Fig. 8c right).

The cross sections and fracture surfaces of samples containing admixed master alloys are presented in Fig. 9. Line EDS scanning on the interface between the Fe particle and master alloys MA1 and MA2 shows that at least at this temperature there is no significant interaction between the different particles. No intermediate compounds seem to be formed on the interface, and changes in the composition of the $\mathrm{Fe}$ particles are almost negligible. In case of steels containing MA3 (Cr containing), there seems to be a more significant diffusion of alloying elements into the Fe base particles. The points located on the interface (such as point 4 in Fig. 9) present a different composition than the areas located inside the master alloy particle or in the base particles. This suggests the possible formation of new phases on the interface, probably favored by the high $\mathrm{Cr}$ content in this master alloy.

The fracture surfaces of steels containing master alloys, shown in Fig. 9-right, present much cleaner surfaces than those observed in Mn-containing steels. In this case, the oxides seem to be concentrated on the surfaces of the master alloy particles and are rarely found on the surrounding Fe base particles. The concentration of oxides on the surface of the master alloy particles is clearly shown in 
Fig. 8 SEM images of compacts sintered in $\mathrm{Ar}$ at $900{ }^{\circ} \mathrm{C}$ for $1 \mathrm{~h}$ : cross section of the sample and EDS line scanning in the interface (left), fracture surface $(r i g h t)$.

a $\mathrm{Fe}+0.5$ mass $/ \% \mathrm{C}+4$ mass $/ \% \mathrm{Cr}$, b Fe +0.5 mass $/ \%$ $\mathrm{C}+4 \mathrm{mass} / \% \mathrm{Mn}, \mathbf{c} \mathrm{Fe}+0.5$ mass $/ \% \mathrm{C}+4$ mass $/ \% \mathrm{Si}$. The composition values showed only allow qualitative interpretation, as the technique used does not provide quantitative information
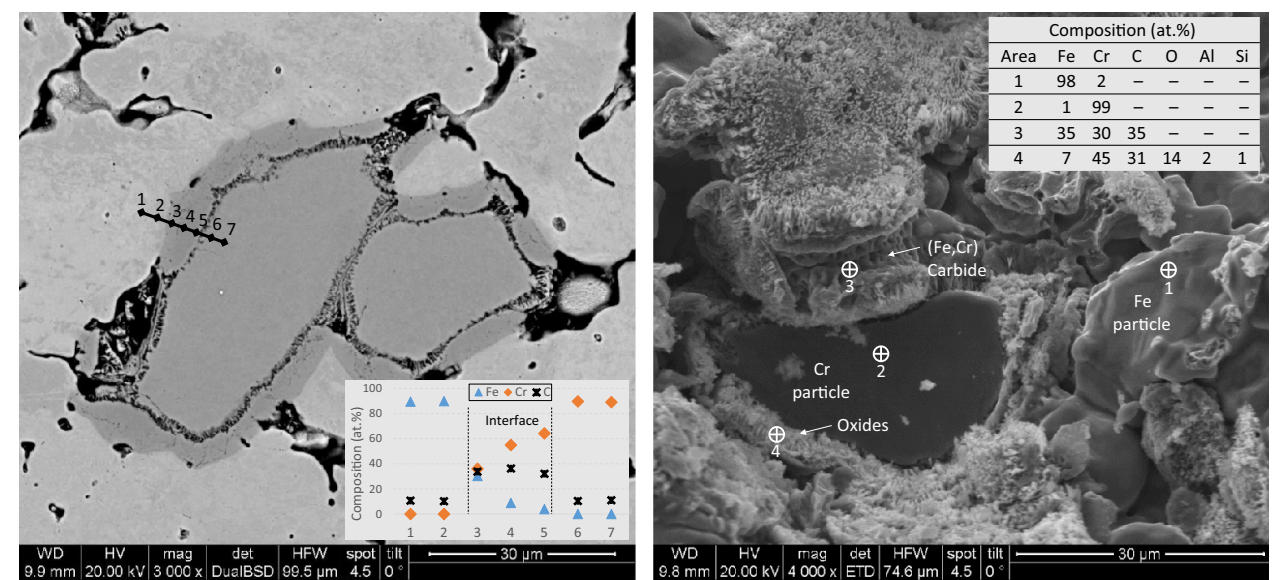

(a) $\mathrm{Fe}+0.5 \mathrm{C}+4 \mathrm{Cr}$
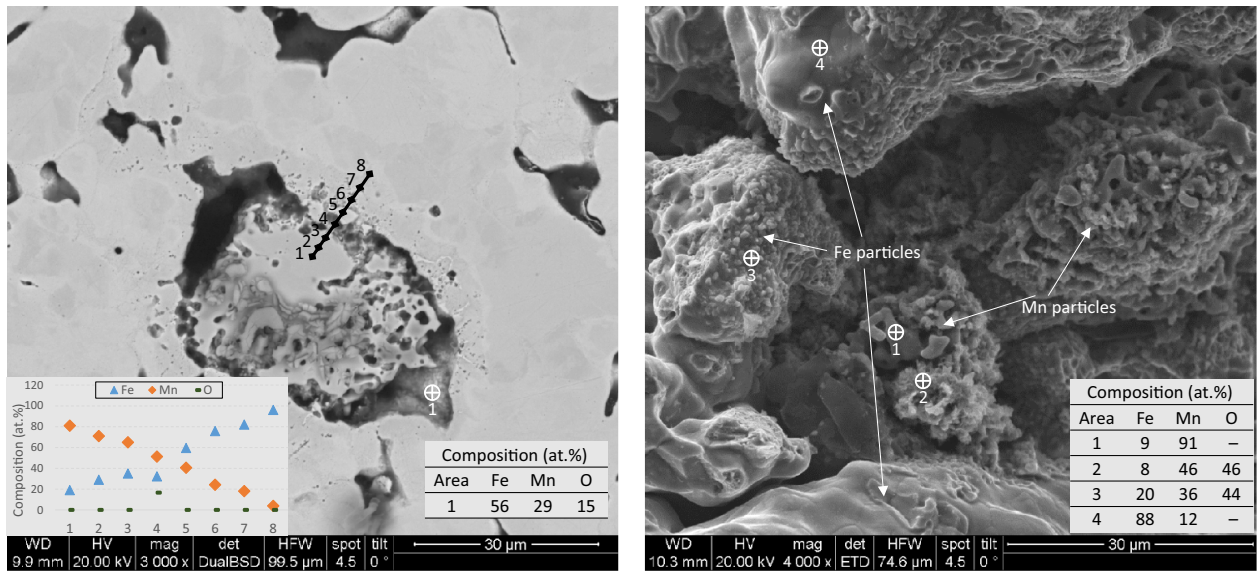

(b) $\mathrm{Fe}+0.5 \mathrm{C}+4 \mathrm{Mn}$
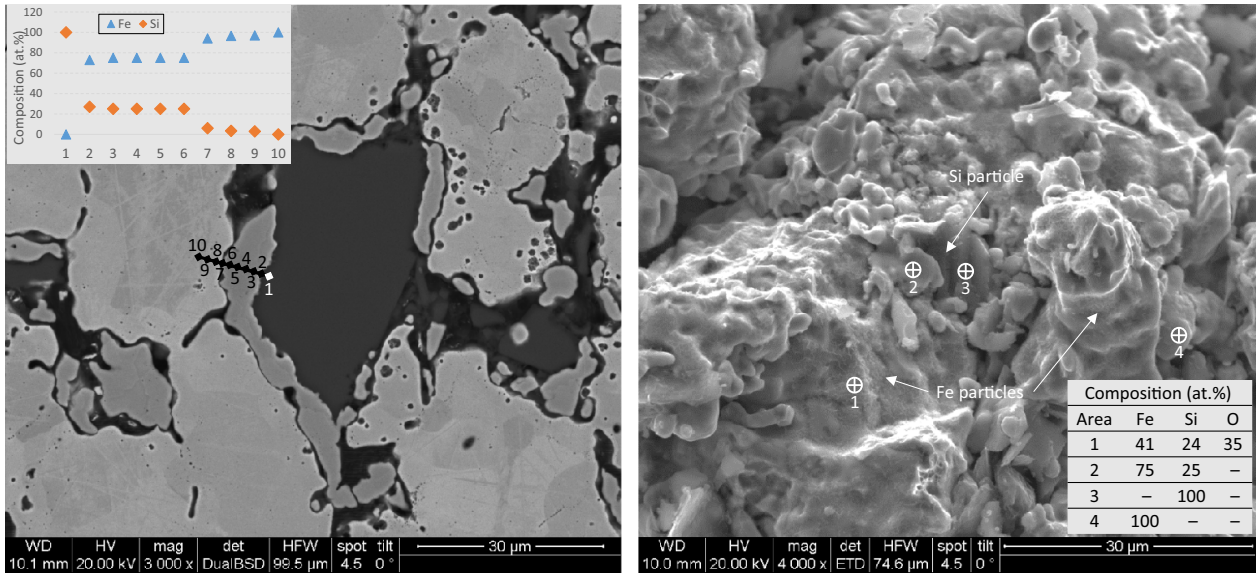

(c) $\mathrm{Fe}+0.5 \mathrm{C}+4 \mathrm{Si}$
Fig. 9a, c. In both cases, the fracture process has revealed internal areas of the master alloy particles (point 1 in both Fig. 9a, c) where no oxygen is detected. In contrast, the surface of the master alloy particles (point 2 in Fig. 9aright, point 1 in Fig. 9b-right, point 2 in Fig. 9b-right) is enriched in oxygen.

The master alloy powders used in this study were gas atomized in $\mathrm{N}_{2}$ and had very low oxygen contents. The surface was analyzed in previous studies [28] and showed a thin iron oxide layer (of approximately $1 \mathrm{~nm}$ ) that covers most of the particle. However, after sintering at $900{ }^{\circ} \mathrm{C}$, the surface of the master alloy particles is oxidized. As indicated by thermal analysis, the source of oxygen is not the sintering atmosphere but the iron powder itself (since the mass remains constant during the reduction of the iron oxide on the base particles). The morphology of the surface 
Fig. 9 SEM images of compacts sintered in Ar at $900{ }^{\circ} \mathrm{C}$ for $1 \mathrm{~h}$ : cross section of the sample and EDS line scanning in the interface (left), fracture surface (right).

a $\mathrm{Fe}+0.5$ mass $/ \% \mathrm{C}+4$ mass $/ \%$ MA1 (Fe-40Mn-17Si), b $\mathrm{Fe}+0.5$ mass $/ \% \mathrm{C}+4$ mass $/ \%$ MA2 (Fe-40Mn-15Si$1 \mathrm{C}), \mathbf{c ~} \mathrm{Fe}+0.5 \mathrm{mass} / \% \mathrm{C}+4$ mass $/ \%$ MA3 (Fe-40Mn-10Si$15 \mathrm{Cr}-0.5 \mathrm{C})$. The composition values showed only allow qualitative interpretation, as the technique used does not provide quantitative information
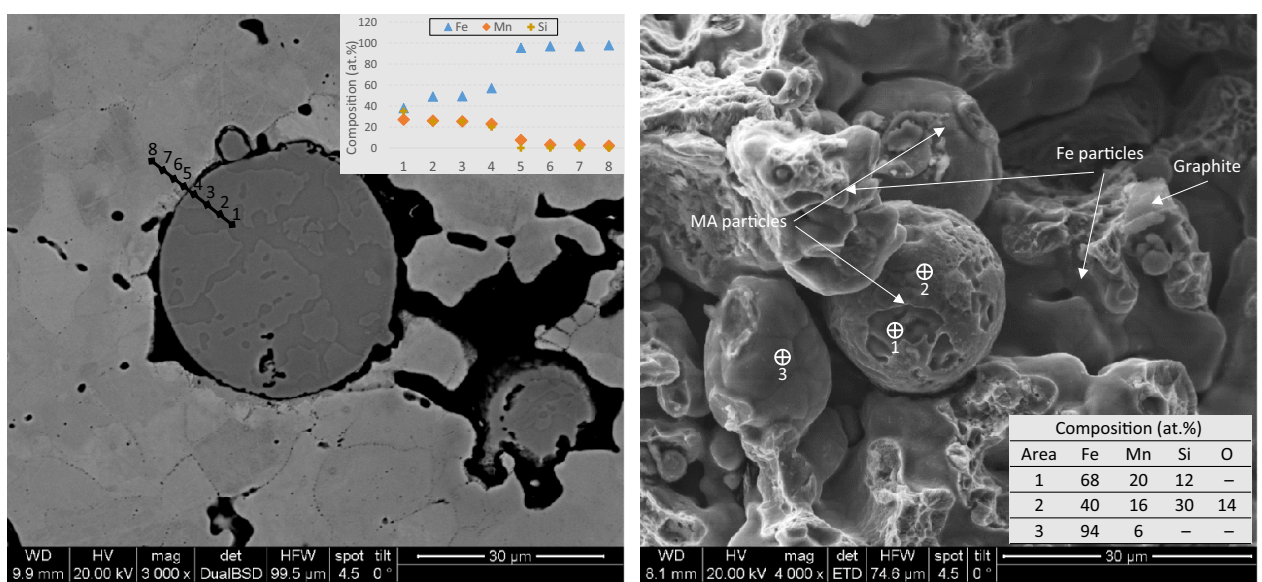

(a) $\mathrm{Fe}+0.5 \mathrm{C}+4 \mathrm{MA} 1(\mathrm{Fe}-40 \mathrm{Mn}-17 \mathrm{Si})$

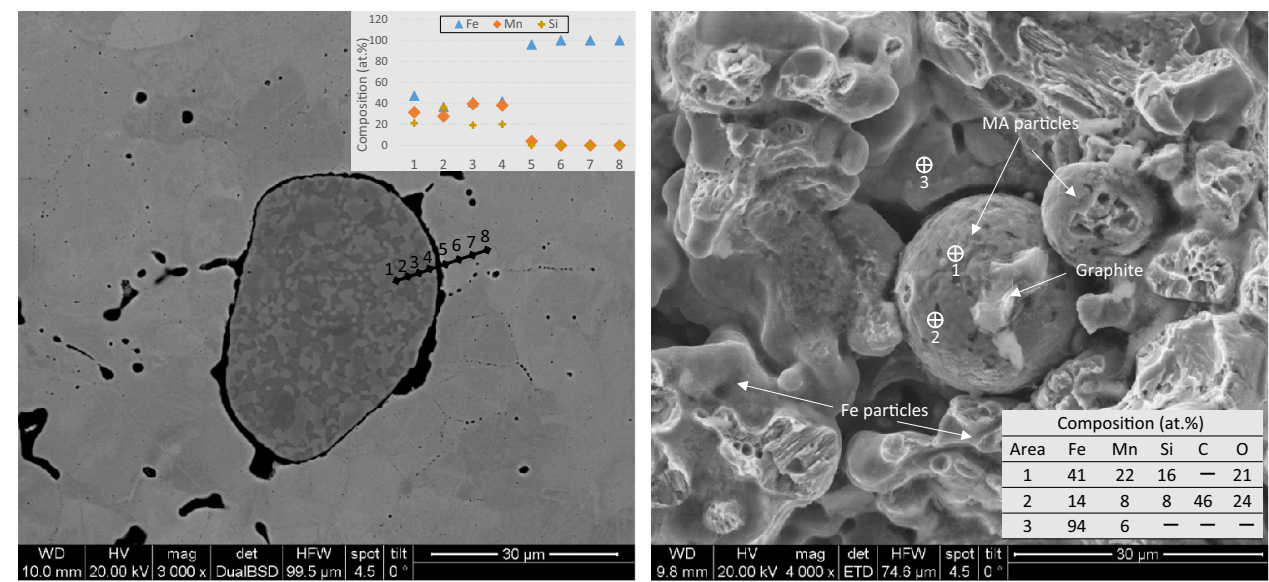

(b) $\mathrm{Fe}+0.5 \mathrm{C}+4 \mathrm{MA} 2(\mathrm{Fe}-40 \mathrm{Mn}-15 \mathrm{Si}-1 \mathrm{C})$
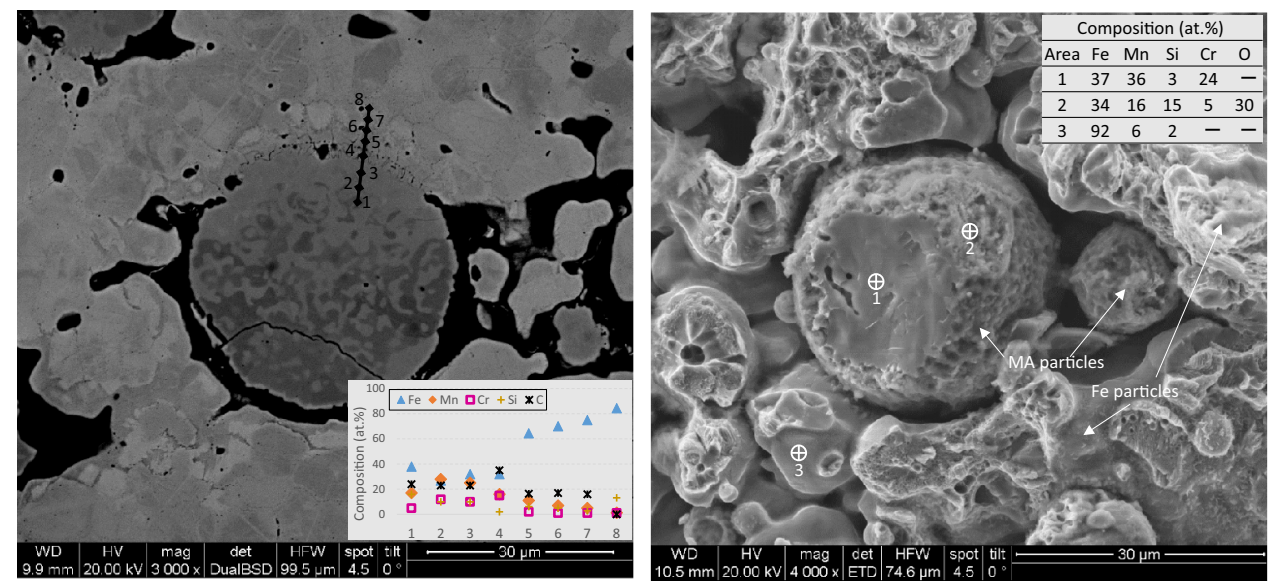

(c) $\mathrm{Fe}+0.5 \mathrm{C}+4 \mathrm{MA} 3(\mathrm{Fe}-40 \mathrm{Mn}-10 \mathrm{Si}-15 \mathrm{Cr}-0.5 \mathrm{C})$

of MA1 and MA2 after sintering at $900{ }^{\circ} \mathrm{C}$ is different from that of MA3. MA1 and MA2 exhibit a smooth surface that suggests the presence of an oxide layer relatively homogeneous in thickness. MA3 in contrast presents a more heterogeneous surface in which the oxide layer seems to be thicker. This is in agreement with the oxidation/reduction processes observed with thermal analysis, which showed that due to the addition of $\mathrm{Cr}, \mathrm{MA} 3$ is a more effective oxygen getter and therefore promotes the concentration of oxides on its surface.

Even though the oxygen-gettering effect is not completely avoided by the use of master alloys, the distribution of the oxides is considerably different compared to that observed in steels with Mn. The presence of oxides on the Fe base particles surrounding the alloy element carrierswhich have been proved to damage the mechanical 
performance-is considerably reduced when using master alloys. The oxidation/reduction behavior is improved-as compared with the addition of elemental alloying powders-even in the case of MA3 which contains in total 65 mass/\% of alloying elements with a high oxygen affinity. In terms of oxidation/reduction behavior, the master alloy route is therefore an interesting way of introducing elements like $\mathrm{Mn}$ in sintered steels, providing improved compressibility compared with the use of Mn-prealloyed powders, and hindering the formation of oxides in iron grain boundaries that is typical for Mn steels produced from electrolytic Mn or ferro-Mn powders [14, 15, 26].

On the other hand, when using master alloy particles, diffusion of alloying elements is enhanced by the melting of the master alloy particles. The presence of oxides on the interface between the liquid master alloy and the iron base particles has an impact on the wetting behavior of the liquid, and this seems to affect its dimensional behavior [6]. For these reasons, it is necessary to adjust the composition of the master alloy, and/or the sintering processes, in order to minimize the concentration of oxides on the surface of the master alloy particles. Sintering in $\mathrm{H}_{2}$ containing atmospheres is an interesting option because it allows reduction of the iron oxides at $400{ }^{\circ} \mathrm{C}$ [2]. At these temperatures, the reactivity of the master alloys is much lower, which considerably reduces the oxygen-gettering or "internal gettering" effect [23]. Also special attention needs to be taken during the delubrication cycles usually performed at temperatures around $600-900{ }^{\circ} \mathrm{C}$. This is a very critical stage of the process since, in this temperature range, $\mathrm{Mn}$ and $\mathrm{Cr}$ have shown to be very sensitive to oxidation. In laboratory tests, delubrication processes at $400{ }^{\circ} \mathrm{C}$ have been proved to be sufficient for a proper removal of the lubricant [29], and this lower temperature would considerably reduce the risks of oxidation of the master alloy particles. However, it should be checked if these conditions afford satisfactory delubrication also in industrial practice.

\section{Conclusions}

Thermal analysis techniques have been used to identify the oxidation/reduction processes taking place when sintering steels containing oxidation-sensitive elements.

- Thermal analysis studies on pure oxides $\mathrm{Fe}_{2} \mathrm{O}_{3}, \mathrm{MnO}_{2}$, $\mathrm{Fe}_{2} \mathrm{MnO}_{4}, \mathrm{Cr}_{2} \mathrm{O}_{3}$ and $\mathrm{SiO}_{2}$ provide the critical temperatures at which these oxides can be reduced by carbothermal mechanisms under the conditions used in these experiments. Fe oxides are completely reduced between 800 and $1050{ }^{\circ} \mathrm{C} ; \mathrm{Cr}_{2} \mathrm{O}_{3}$ presents a single reduction stage at $\sim 1136{ }^{\circ} \mathrm{C}$, while $\mathrm{MnO}_{2}$ is reduced to $\mathrm{MnO}$ below $1000{ }^{\circ} \mathrm{C}$, but reduction of $\mathrm{MnO}$ requires temperatures around $\sim 1373{ }^{\circ} \mathrm{C}$. $\mathrm{SiO}_{2}$ is the most stable oxide; its carbothermal reduction starts only above $1200{ }^{\circ} \mathrm{C}$ and is not completely registered in these experiments.

- Analysis of the reduction processes on metallic powders suggests an enhancement of the carbothermal reduction processes due to the fact that the oxides are located on the surface of metallic powders, being able to diffuse into the base metal. This effect is indicated both by the lower temperatures required to reduce the oxides present on the surface of $\mathrm{Fe}$ powders and also when sintering Mn-containing steels, for which the reduction processes occur at much lower temperatures than those required for the reduction of $\mathrm{MnO}$.

- Powder particles containing elements with a high oxygen affinity act as "internal getter" agents, which means that they are oxidized by the gaseous products from the reduction of iron oxides. This causes an oxygen transfer from the surface of the iron base powder to the oxygen-sensitive alloying elements.

- The susceptibility of different alloying elements to this oxygen-gettering effect is different, being more significant for $\mathrm{Mn}$ and $\mathrm{Cr}$ than for $\mathrm{Si}$. The reason is that the former ones present a higher tendency for oxidation in the critical temperature range where the reduction of the iron oxides takes place. Combination of these alloying elements in the form of a master alloy powder is an interesting alternative to reduce the internalgettering effect.

- The location and morphology of the oxides formed through the "internal getter" effect depend on the alloying elements used. In steels containing admixed $\mathrm{Cr}$, the oxides remain enclosed by a carbide shell formed at the interface. In case of Mn, particulate oxides are often found embedded on the surfaces of the iron base particles surrounding the Mn particles, which can have a significant effect on the final mechanical properties. This latter effect is avoided when Mn is introduced as a master alloy, in which case the oxides tend to form a layer on the surface of the master alloy particles.

- Even though the internal getter effect is reduced by the use of master alloy, the concentration of oxides on the surface of the master alloy particles at $900{ }^{\circ} \mathrm{C}$ is evident. It is therefore important to adjust the sintering conditions (particularly atmospheres and heating rates) to avoid possible oxygen transfers between powder particles. Besides, since the sensitivity of different alloying elements to oxidation is different, the combination of elements in the master alloy powder can be advantageously designed to reduce its sensitivity to oxidation. 
Acknowledgements Open access funding provided by TU Wien (TUW). The research leading to these results has received funding from the People Programme (Marie Curie Actions) of the European Union's Seventh Framework Programme FP7/2007-2013/under REA Grant Agreement No. 625,556. The support from the European Research Commission through the People work program FP7-PEOPLE-2013-IEF is very gratefully acknowledged.

Open Access This article is distributed under the terms of the Creative Commons Attribution 4.0 International License (http://crea tivecommons.org/licenses/by/4.0/), which permits unrestricted use, distribution, and reproduction in any medium, provided you give appropriate credit to the original author(s) and the source, provide a link to the Creative Commons license, and indicate if changes were made.

\section{References}

1. Danninger H, Gierl C. Processes in PM steel compacts during the initial stages of sintering. Mater Chem Phys. 2001;67(1-3): 49-55.

2. Danninger H, Gierl C. New alloying systems for ferrous powder metallurgy precision parts. Sci Sinter. 2008;40(1):33-46. doi:10. 2298/sos0801031d.

3. Danninger H, Gierl C, Kremel S, Leitner G, Jaenicke-Roessler K, $\mathrm{Yu}$ Y. Degassing and deoxidation processes during sintering of unalloyed and alloyed PM Steels. Powder Metall Prog. 2002;2(3):125-40.

4. Albano-Müller L, Thümmler F, Zapf G. High-strength sintered iron-base alloys by using transition metal carbides. Powder Metall. 1973;16:236-56.

5. Zapf G, Dalal K. Introduction of high oxygen affinity elements manganese, chromium and vanadium in the powder metallurgy of P/M parts. Mod Dev Powder Metall. 1977;10:129-52.

6. Oro Calderón R, Bernardo E, Campos M, Gierl-Mayer C, Danninger H, Torralba JM. Tailoring master alloys for liquid phase sintering: Effect of introducing oxidation-sensitive elements. Powder Metall. 2016. doi:10.1080/00325899.2016.1148897.

7. Chasoglou D, Hryha E, Nyborg L. Effect of sintering atmosphere on the transformation of surface oxides during the sintering of chromium alloyed steel. Powder Metall Prog. 2009;9(3):141-55.

8. Chasoglou D, Hryha E, Nyborg L. Effect of process parameters on surface oxides on chromium-alloyed steel powder during sintering. Mater Chem Phys. 2013;138(1):405-15. doi:10.1016/j. matchemphys.2012.11.074.

9. Gierl-Mayer C, Oro Calderon R, Danninger H. The role of oxygen transfer in sintering of low alloy steel powder compacts: a review of the "internal getter" effect. JOM. 2016. doi:10.1007/ s11837-016-1819-z.

10. Oro R, Campos M, Torralba JM, Capdevila C. Lean alloys in PM: from design to sintering performance. Powder Metall. 2012;55(4):294-301. doi:10.1179/1743290112Y.0000000016.

11. Gruner W, Stolle S, Wetzig K. Formation of COx species during the carbothermal reduction of oxides of $\mathrm{Zr}, \mathrm{Si}, \mathrm{Ti}, \mathrm{Cr}, \mathrm{W}$, and $\mathrm{Mo}$. Int J Refract Metal Hard Mater. 2000;18(2-3):137-45. doi:10. 1016/S0263-4368(00)00013-5.

12. Mitchell SC, Cias A. Carbothermic reduction of oxides during nitrogen sintering of manganese and chromium steels. Powder Metall Prog. 2004;4(3):132-42.
13. Salak A. Sintered Manganese Steels. Manganese Evaporation During Sintering. Powder Metall Int. 1980;12(2):72-5.

14. Hryha E, Dudrova E. The sintering behaviour of $\mathrm{Fe}-\mathrm{Mn}-\mathrm{C}$ powder system, correlation between thermodynamics and sintering process, Mn distribution, and microstructure. Prog Powder Metall. 2007;534-536:761-4.

15. Hryha E, Dudrova E, Nyborg L. Critical aspects of alloying of sintered steels with manganese. Metall Mater Trans A. 2010;41A(11):2880-97. doi:10.1007/s11661-010-0357-5.

16. Hryha E, Nyborg L. Thermogravimetry study of the effectiveness of different reducing agents during sintering of Cr-prealloyed PM steels. J Therm Anal Calorim. 2014;118(2):825-34. doi:10.1007/ s10973-014-3915-z.

17. Hryha E, Borgström H, Sterky K, Nyborg L. Influence of the steel powder type and processing parameters on the debinding of PM compacts with gelatin binder. $\mathrm{J}$ Therm Anal Calorim. 2014;118(2):695-704. doi:10.1007/s10973-014-3839-7.

18. Hryha E, Gierl C, Nyborg L, Danninger H, Dudrova E. Surface composition of the steel powders pre-alloyed with manganese. Appl Surf Sci. 2010;256(12):3946-61. doi:10.1016/j.apsusc. 2010.01.055.

19. Karlsson H, Nyborg L, Berg S. Surface chemical analysis of prealloyed water atomised steel powder. Powder Metall. 2005;48(1):51-8. doi:10.1179/0032589005x37675.

20. Nyborg L, Norell M, Olefjord I. Surface studies of powder metallurgical stainless-steel. Surf Interface Anal. 1992;19(1-12):607-14.

21. Nyborg L, Nylund A, Olefjord I. Thickness determination of oxide layers on spherically-shaped metal powders by ESCA. Surf Interface Anal. 1988;12(1-12):110-4.

22. Hryha E, Nyborg L. Oxide transformation in $\mathrm{Cr}-\mathrm{Mn}$-prealloyed sintered steels: thermodynamic and kinetic aspects. Metall Mater Trans A. 2014;45(4):1736-47. doi:10.1007/s11661-013-1969-3.

23. Oro R, Campos M, Gierl-Mayer C, Danninger H, Torralba J. New alloying systems for sintered steels: critical aspects of sintering behavior. Metall Mater Trans A. 2015;46(3):1349-59. doi:10. 1007/s11661-014-2707-1.

24. Danninger H, Kara T, Ruhnow M, Ullrich H-J. Microprobe analysis of low alloyed sintered steels. Mikrochim Acta. 1990;101(1-6):219-29. doi:10.1007/BF01244174.

25. Danninger H. Low alloy chromium steels for highly loaded PM parts. 8th International conference on powder metallurgy in the CSFR; Piestany: Institute for Materials Research of the Slovak Academy of Sciences (IMR SAS); 1992. pp. 81-90.

26. Hryha E, Nyborg L, Dudrová E, Bengtsson S. Brittleness of structural PM steels admixed with manganese studied by advanced electron microscopy and spectroscopy. Powder Metall Prog. 2008;8(2):109-14.

27. Zhang Y, Ivey D. Fe3Si formation in $\mathrm{Fe}-\mathrm{Si}$ diffusion couples. J Mater Sci. 1998;33(12):3131-5.

28. Oro R, Campos M, Hryha E, Torralba JM, Nyborg L. Surface phenomena during the early stages of sintering in steels modified with $\mathrm{Fe}-\mathrm{Mn}-\mathrm{Si}-\mathrm{C}$ master alloys. Mater Charact. 2013;86:80-91. doi:10.1016/j.matchar.2013.07.022.

29. Karamchedu S, Hryha E, Nyborg L. Changes in the surface chemistry of chromium-alloyed powder metallurgical steel during delubrication and their impact on sintering. J Mater Process Technol. 2015;223:171-85. doi:10.1016/j.jmatprotec.2015.03. 054. 